NBER WORKING PAPER SERIES

\title{
AN EVENT STUDY OF COVID-19 CENTRAL BANK QUANTITATIVE EASING IN ADVANCED AND EMERGING ECONOMIES
}

\author{
Alessandro Rebucci \\ Jonathan S. Hartley \\ Daniel Jiménez \\ Working Paper 27339 \\ http://www.nber.org/papers/w27339 \\ NATIONAL BUREAU OF ECONOMIC RESEARCH \\ 1050 Massachusetts Avenue \\ Cambridge, MA 02138 \\ June 2020, Revised June 2022
}

Paper prepared for the Conference in Honor of M. Hashem Pesaran. We thank Alexander Chudik, Cheng Hsiao, and Allan Timmermann (the conference organizers) M. Hashem Pesaran and conference participants for comments and suggestions. We are also grateful to Rashad Ahmed, Gianluca Benigno, Rich Clarida, Tito Cordella, Karen Dynan, Jason Furman, Alicia Garcia Herrero, Daniel Nathan, Elina Ribakova, Siyi Shen, Jeongwon Son, Stephen Williamson, Beth Wilson, Stefania D'Amico and Charles Wyplosz for helpful comments and discussions. Reid Brotmann provided excellent research assistance. All remaining errors are of the authors. The views expressed herein are those of the authors and do not necessarily reflect the views of the National Bureau of Economic Research.

NBER working papers are circulated for discussion and comment purposes. They have not been peer-reviewed or been subject to the review by the NBER Board of Directors that accompanies official NBER publications.

(C) 2020 by Alessandro Rebucci, Jonathan S. Hartley, and Daniel Jiménez. All rights reserved. Short sections of text, not to exceed two paragraphs, may be quoted without explicit permission provided that full credit, including () notice, is given to the source. 
An Event Study of COVID-19 Central Bank Quantitative Easing in Advanced and Emerging Economies

Alessandro Rebucci, Jonathan S. Hartley, and Daniel Jiménez

NBER Working Paper No. 27339

June 2020, Revised June 2022

JEL No. E52,E58,F42,G14,I28

\section{$\underline{\text { ABSTRACT }}$}

This paper conducts an event study of 30 quantitative easing (QE) announcements made by 21 central banks on daily government bond yields and bilateral US dollar exchange rates in March and April 2020, in the midst of the global financial turmoil triggered by the COVID-19 outbreak. The chapter also investigates the transmission of innovations to long-term interest rates in a standard GVAR model estimated with quarterly pre-COVID-19 data. The authors find that QE has not lost effectiveness in advanced economies and that its international transmission is consistent with the working of long-run uncovered interest rate parity and a large dollar shortage shock during the COVID-19 period. In emerging markets, the QE impact on bond yields is much stronger and its transmission to exchange rates is qualitatively different than in advanced economies. The GVAR evidence that the authors report illustrates the Fed's pivotal role in the global transmission of long-term interest rate shocks, but also the ample scope for countryspecific interventions to affect local financial market conditions, even after controlling for common factors and spillovers from other countries. The GVAR evidence also shows that QE interventions can have sizable real effects on output driven by a very persistent impact on longterm interest rates.

Alessandro Rebucci

Johns Hopkins Carey Business School

100 International Drive

Baltimore, MD 21202

and NBER

arebucci@jhu.edu

Jonathan S. Hartley

Stanford University

579 Jane Stanford Way

Stanford, CA 94305

hartleyj@stanford.edu
Daniel Jiménez

International Monetary Fund

700 19th Street, N.W.

Washington, D.C. 20431

djimenez@imf.org 


\section{Introduction}

Faced with short-term interest rates nearing zero, during the Great Recession era, major advancedeconomy central banks adopted unconventional monetary policies in the form of large-scale asset purchases. These operations typically targeted government or government-backed securities and are commonly referred to as quantitative easing $(\mathrm{QE})$. Hitherto enacted primarily by the US Federal Reserve, the European Central Bank, the Bank of Japan, and the Bank of England as well as the Swiss National Bank and the Riksbank of Sweden, amid COVID-19, a few other developed and several emerging market central banks adopted this form of intervention for the first time, also broadening the range of securities purchased.

In this paper, we present both daily-frequency evidence on this episode of "global QE," which provides some confidence in identifying the financial market impacts, and quarterly pre-COVID19 evidence that permits assessing the longer-term effects. We conclude from these two separate bodies of evidence that country-specific QE can have stabilizing effects in financial markets and a supportive impact on real economic activity, over and above the spillovers from the QE actions of major central banks and the large role played by global common factors in the transmission.

The set of interventions that we consider includes 30 COVID-19 QE announcements from 21 central banks around the world in March and April 2020. We focus on 10-year government bonds purchases and their impact on bond yields because this is the predominant type of asset purchases across all central banks engaged in QE and, for comparison with the Great Recession era interventions. We also estimate the effects on bilateral exchange rates because of the pivotal role of the US dollar in the international financial system.

To estimate the impact of country-specific QE interventions with a reasonable degree of confidence on their causal nature, we adopt a typical event study design used to analyze the effects of the Great Recession era QE on bond yields - for example, Krishnamurthy and Vissing-Jorgensen (2011), Swanson, Reichlin and Wright (2011), and Gagnon, Raskin, Remache and Sack (2010). This approach to identification, originally proposed by Fama, Fisher, Jensen and Roll (1969), has the advantage of being simple and transparent. Moreover, our large set of QE events allows us 
to conduct some robustness analysis, controlling for concomitant interest rate cuts and asset purchases in other security markets.

Nevertheless, we are mindful of the challenges of establishing the causal effect of individual interventions in the context of such a global, uncoordinated, and staggered QE action (Cao and Dowd, 2019, Elenev, Quintero, Rebucci and Simeonova, 2020). Therefore, we regard the event study's primary goal as to establish a set of new stylized facts on this special episode of global QE under COVID-19 and discuss alternative interpretations of the evidence that we report. In particular, two important questions cannot be easily addressed with a high-frequency event analysis. The first is whether the QE impacts that we estimate are a mere result of the global reach of the Fed or reflects genuine country-specific effects. This is because only the Croatian central bank intervened before the Fed on March 13, 2020. The second question is whether the financial market impact of the country-specific QE interventions that we analyze can ultimately also affect real macroeconomic outcomes, consistent with the objectives of the adopting central banks.

To illustrate the challenge of disentangling the impact of the Fed's actions from that of other central banks' interventions, Fig. 1 plots an indicator closely associated with the world nominal interest rate together with the Fed's nominal effective exchange rate. The figure shows that both this proxy of the world interest rate and the dollar index turned around in coincidence with the Fed QE announcements and the reinstatement and expansion of the Great Recession era swap lines. Thus, possibly suggesting that the estimated impacts of country-specific QE in our event study may capture mostly the global reach of the Fed's actions. Nonetheless, if we look at individual countries, reported in Appendix Figure B.1 and B.2, we can also see that many, albeit not all, turning points in local bond yields and bilateral exchange rates are associated with country-specific QE actions.

To address the broad questions above, but also to help interpret the estimation results, we rely on pre-COVID-19 quarterly data and the global vector auto regression (GVAR) methodology initially proposed by Pesaran, Schuermann and Weiner (2004) and Dees, Mauro, Pesaran and Smith (2007) and further developed by Cesa-Bianchi, Pesaran, Rebucci, Xu and Chang (2012) and 
Figure 1 The World Interest Rate, the US Dollar, and the Fed

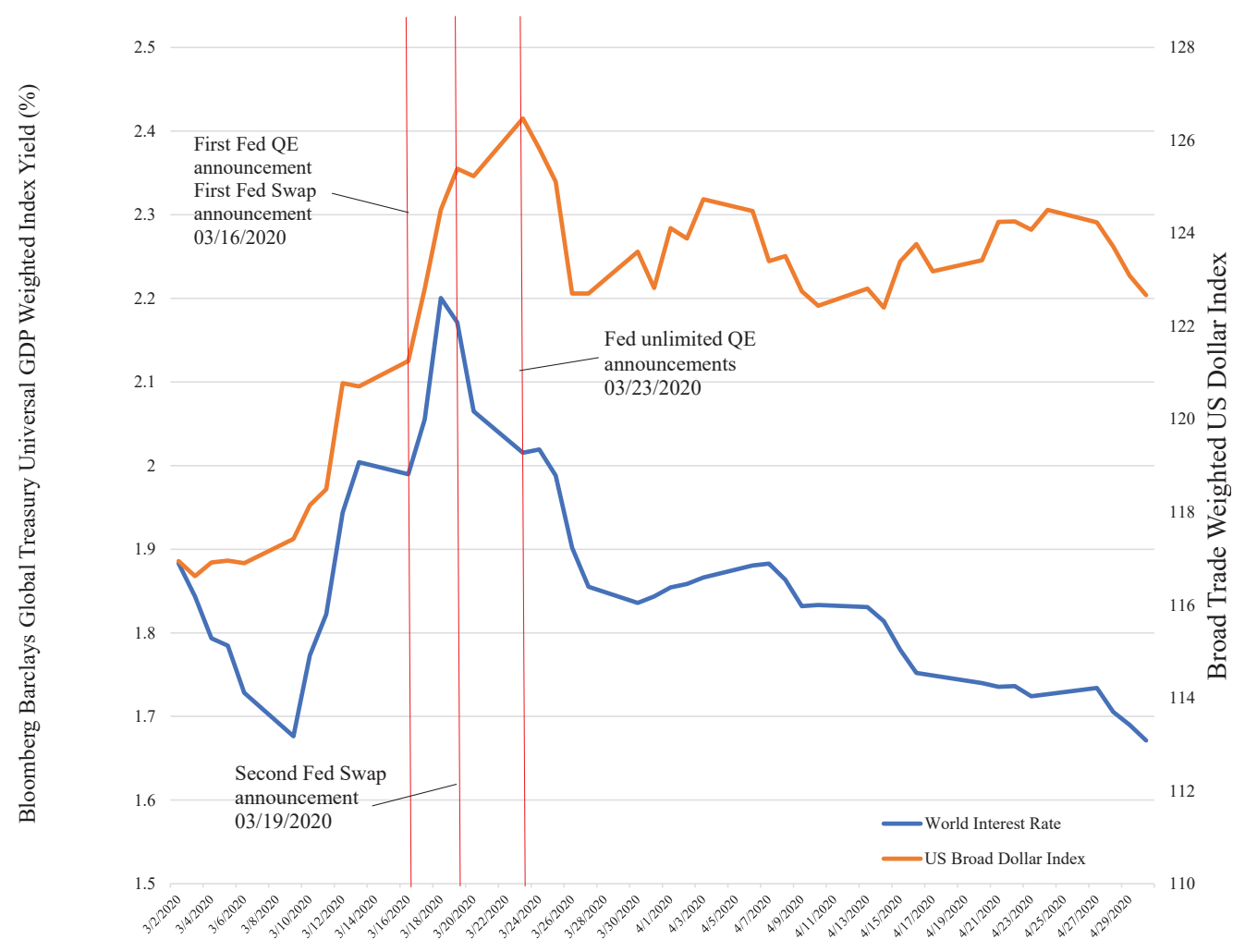

NOTE. The figure plots the yield for the Bloomberg Barclays Global Treasury Universal GDP Weighted Index and the US nominal effective exchange rate index (Fed Broad Index, H.10 release). The Bloomberg Barclays Global Treasury Universal Index tracks fixed rate, local-currency government debt in both developed and emerging markets. The index represents the treasury sector of the Barclays Global Aggregate Universal Index and contains issues from 51 countries. The index uses GDP (a proxy of a country's ability to service its debt) as the basis for country-level weights. Monthly rebalancing occurs for underlying bonds entering and exiting the specific country sub-indices. The vertical bars indicate the Fed QE and swap intervention dates listed in Table 1 below.

Cesa-Bianchi, Pesaran and Rebucci (2020) among others. GVAR modeling is particularly suitable to address these questions since it permits estimation of the impact of country-specific innovations to long-term interest rates holding constant both common factors, including the world interest rate, and spillovers from other countries' implementation of similar policy measures, including the Federal Reserve.

In the event analysis, we find evidence that QE policy has not lost effectiveness over time, even though unequivocally unexpected announcements have much larger impacts on bond yields than more predictable ones. In developed markets, the average COVID-19 QE announcement has had an estimated single-day impact of -13bps on the implementing country's 10-year government 
bond yield and a cumulative impact over the following two and three days of -13bps and -10bps, respectively. By contrast, in emerging markets, the average COVID-19 QE announcement has had an estimated -23bps single-day impact on bond yields, and a -38bps and -42bps cumulative impact over the following two and three days. Impacts on dollar exchange rates are much more varied across countries. The most striking finding here is that, during COVID-19, on average, QE announcements are associated with larger depreciation in advanced economies than in emerging markets; a finding that stands in sharp contrast to the experience of these countries during the global financial crisis in 2008-2009. These main results are robust to controlling for the concomitant reduction of policy rates or intervention in other asset markets, as well as the exclusion of subsequent announcements.

In advanced economies, the estimated effects on bond yields and exchange rates are consistent with the working of long-run uncovered interest rate parity (UIP) and the presence of a large dollar shortage shock in the data, to which the Fed responded with enhanced and extended swap lines. The same framework, however, cannot explain emerging market behaviors. To interpret the emerging market results, we need to assume either an additional countervailing country-specific foreign exchange supply shock through interventions or, a different mechanism explaining the transmission at work.

The GVAR evidence that we report illustrates the important role of global factors and the pivotal role of the US Fed in the transmission of innovations to long-term interest rates. Nonetheless, it also illustrates how country-specific interventions can have sizable domestic effects on long rates, the real exchange rate, and ultimately output, with limited spillovers beyond regional effects. Critically, we show that the impact of these innovations on long rates are very persistent, especially in advanced economies. The GVAR results also document the presence of a dollar factor in bilateral exchange rates after controlling for a world interest rate factor, the international business cycle, global monetary conditions, inflation, and the global financial cycle. Moreover, the GVAR results also show that advanced economies load onto this factor much more than emerging markets, consistent with the results of the event analysis, thus providing scope for country-specific policy 
interventions.

Overall, our event study and GVAR analysis results show that the Fed played a critical role in stabilizing bond markets worldwide and partially addressing the global dollar shortage triggered by the COVID-19 outbreak. Nevertheless, our findings also provide abundant evidence that country-specific QE interventions contributed significantly and effectively to stabilize local bond and exchange rate markets, after controlling for the Fed's actions, other confounding factors, and spillovers from other central banks' interventions. This evidence is consistent with a narrative that the Fed is critical for the stability of global capital markets but it leaves ample scope for additional stabilization gains from individual countries' actions.

Related Literature The chapter naturally relates to the literature on the evaluation of the financial market impact of QE interventions during and after the Great Recession era. Gagnon, Raskin, Remache and Sack (2010) estimate that the first round of Fed QE in 2008 (QE1) reduced the US term premium in a range between $30 \mathrm{bps}$ and $150 \mathrm{bps}$ at different maturities. They also find that this program affected other assets not targeted directly such as corporate bond yields. However, the study considers not just the initial announcements but also all subsequent statements that affirm the continuation of the program, which might therefore include confounding new information about forward guidance. Krishnamurthy and Vissing-Jorgensen (2011) examine the effect of Treasury and MBS purchase announcements under both the first and the second round of Fed QE intervention in 2008-2009. They find that the QE1 announcement lowered MBS yields as well as corporate spreads. D'Amico and King (2013) analyze the impact of Federal Reserve QE1 Treasury purchases during 2009 finding that there is an additional decline of $0.035 \%$ in the yields of specific bonds on the dates they were purchased in addition to a $0.30 \%$ overall impact on Treasuries yields during QE1. In contrast, Treasuries-only purchases under QE2 had a disproportionate effect on the yield of the targeted securities and agency bond yields relative to MBS yields. Swanson et al. (2011) examine five different announcements from Operation Twist (the Fed's maturity extension program that occurred in the 1960s) and compare these impacts with QE2. He finds that they cumulatively lowered long-term Treasury yields by $15 \mathrm{bps}$ on average across the five announcements. Krishna- 
murthy et al. (2018) analyze the European Central Bank's (ECB) Securities Markets Program and the Outright Monetary Transactions. They find that these programs had a considerable impact on European sovereign yields and boosted equity prices. Dedola, Georgiadis, Gräb and Mehl (2020) estimate the impact of the Fed and the ECB Great Recession era QE operations on the dollar-euro exchange rate finding large effects similar to those that we document. Joyce, Lasaosa, Stevens and Tong (2011) study the UK case and find that the average yield on five to twenty-five-year Gilts fell by $1 \%$ cumulatively in a 2 -day window surrounding the six announcements they focus on. Greenwood, Hanson, Stein and Sunderam (2020) report exchange rate impacts from 50 preCOVID-19 QE announcements by the Fed, the Bank of Japan, and the United Kingdom, reporting exchange rate impacts of the same magnitude as in our event study. We broaden the set of countries considered during COVID-19 to several other advanced economies and emerging markets.

The literature on the COVID-19 QE era largely focuses on the Fed and the ECB actions. Many papers focus on QE programs targeting new asset classes - see for example, among others, Haddad, Moreira and Muir (2020), Gilchrist et al. (2020), Barbon and Gianinazzi (2019). Other papers have examined the sell-off in Treasuries, with the corresponding rise in yields and fall in liquidity in mid-March 2020. For example, Vissing-Jorgensen (2020) studies the Treasury market dislocations during the initial phase of COVID-19 documenting who the institutional sellers were in addition to analyzing how subsequent Fed interventions stabilized the market. Bahaj and Reis (2020) explore the impact of the Fed swap line announcements finding they were effective at reducing covered interest parity deviations. We evaluate the impact of the swap line announcements on spot exchange rates and discuss the role of the dollar factor in driving them during COVID-19.

Cortes, Gao, Silva and Song (2020), in particular, compare the impact of the Great Recession era QE interventions of the Fed with the effects of the "Global" QE action during COVID-19 on several advanced and emerging countries. The outcome variable is a measure of disaster risk extracted from option pricing of asset-specific exchange traded funds (ETFs). Despite the focus on a higher moment of the data and the different methodology, they find results that are consistent with ours, suggesting that the international transmission of the Fed QE has changed during COVID-19, 
especially in emerging markets. This study provides evidence that complements our event analysis and confirms the importance to control for common factors and spillovers as we do in our empirical analysis.

The adoption of QE in emerging markets has attracted particular attention with contribution from the all major international policy institutions, including the Bank for International Settlements (Hofmann, Shim, Shin et al., 2020), the International Monetary Fund (Sever, Goel, Drakopoulos, Papageorgiou et al., 2020), and the World Bank (Ha and Kindberg-Hanlon, 2020). These studies analyzed announcement effects on bond yields and exchange rates as we do, at daily and intra-daily frequency, and impacts of actual purchases for selected countries. They also attempt to disentangling the effects of country-specific QE from impact of the Fed in the context of panel regression models, but do not control for global factors. We analyze the universe of the QE announcements in these countries, analyzing their effect case-by-case, and comparing them systematically with QE interventions in advanced economies. We also assess the longer-term effect of the policy interventions.

Finally, the GVAR approach uniquely permits us to discuss possible real effects within a coherent multi-country empirical framework that takes global general equilibrium effects into account without restricting the transmission with strong theoretical identification assumptions. Other papers have explored the international transmission of long-term US and Euro Area interest rate shocks interpreted as QE interventions with the GVAR methodology - see, for instance, Colabella (2020) and the references therein. We focus particularly on the relative importance of common versus country-specific interest rate shocks and spillover effects, and also consider the impact on the dollar exchange rate. As far as we are aware, this is the first study to provide a comprehensive set of stylized facts about global QE under COVID-19 in both advanced and emerging markets. This paper proceeds as follows. Section 2 discusses the event study methodology. Section 3 describes the set of announcements that we analyze. Section 4 reports the event study results. Section 5 discusses the event study results relying on GVAR-based, pre-COVID-19 evidence. Section 6 concludes. 


\section{Event Study Methodology}

An event study analysis uses changes in asset prices within short windows of time around known announcement dates to measure the financial market impact of those announcements. The typical event study design used to analyze the impact of QE on bond yields - including Krishnamurthy and Vissing-Jorgensen (2011), Swanson et al. (2011), Gagnon et al. (2010) - closely follows the approach initially proposed by Fama et al. (1969), who make the following critical three assumptions: (i) the event is unexpected, (ii) there are no confounding factors impacting the asset prices being studied, and (iii) that markets are efficient

Although at the onset of the COVID-19 pandemic and economic crisis developed bond markets might have expected a QE policy response, the assumption is quite plausible for emerging markets. In most of these markets, in fact, the policy rate was well above the zero-lower bound, while historically QE was enacted after hitting the zero-lower bound. Even in the case of developed markets, one could argue that the specific timing of the QE interventions could not have been foreseen precisely. Furthermore, to mitigate this concern, similar to Krishnamurthy and VissingJorgensen (2011) and Swanson et al. (2011), we consider only the announcement of QE programs as opposed to the actual bond purchases or the timing of their announcements.

With respect to confounding factors, one concern during COVID-19 is the simultaneous implementation of monetary policy actions, including policy interest rate changes and other unconventional monetary policy actions. The problem of simultaneous announcement of purchases of non-sovereign assets (i.e., corporate bonds, bank assets, equities, EFTs, etc.) spilling over onto sovereign bond yields is particularly severe in the case of the Fed's intervention on March 23, 2020, when the US central bank announced both "unlimited" Treasury and MBS QE as well as its new corporate bond buying facilities. Similarly, the Bank of England, the Bank of Japan, and several emerging market central banks also simultaneously announced corporate bond and government bond purchases or other unconventional interventions.

A second important issue is how to separate the effect of country-specific QE from the global reach of the Fed's interventions. An additional problem specific to the COVID-19 episode that 
we study are the spillover effects from the staggered implementation of QE interventions by many countries at the same time in a relatively short period of time - for example, Elenev et al. (2020). These concerns are particularly acute for emerging markets that are much more sensitive to monetary and financial conditions at the center of the international financial system and have experienced regional contagion in the past.

The large set of events in our sample permits us to control to some extent for the first set of confounding factors by comparing the average QE impacts with and without accompanying interest rate cuts, or including and excluding announcements of interventions in other asset markets. In addition, to address the second set of issues, we will also evaluate the relative importance of global and country-specific innovations to nominal long-term rates, as well as the spillovers of countryspecific innovations conditional on common factors, by drawing on the GVAR methodology with pre-COVID-19 data - for example, Pesaran et al. (2004), Dees et al. (2007), Cesa-Bianchi et al. (2012), and Cesa-Bianchi et al. (2020).

Coming to the third assumption, Jones et al. (1998) and Fleming and Remolona (1999) provide evidence of market efficiency in bond markets in days following major macroeconomic announcements, finding no statistically significant evidence of either momentum or mean-reversion in yields. We also note that the 10-year sovereign bond markets in advanced economies are among the most liquid and efficient (Du et al., 2018), and during crisis times they often become safe-havens, although COVID-19 briefly disrupted even the US government bond market in mid-March 2020 (Schrimpf et al., 2020). In emerging markets, efficiency and liquidity easily evaporate with large local shocks. However, during the initial phase of the pandemic, dollar shortages were more salient at the core of the international financial system, driven by COVID-19 news from China, the United States, and Europe, rather than the spreading to these countries that happened a few weeks later.

That being said, to take into account the likely market inefficiencies during times of financial panic and stress, with respect to the third assumption, in both sets of markets, we consider multipleday event windows. Multi-day windows allow for the possibility that asset prices might not react fully and instantaneously in response to a policy announcement. Krishnamurthy and Vissing- 
Jorgensen (2011) and Swanson et al. (2011) use two-day windows, while Gagnon et al. (2010) use one-day event windows. We consider cumulative changes in sovereign bond yields and percent changes in exchange rates over one-day, two-day, and three-day event windows.

Under these assumptions, one can test the null hypothesis that QE announcements have no statistically significant impact on asset returns. The statistic that we use is the cumulative impact divided by the corresponding unconditional standard deviation for the respective one-, two-, and three-day bond yield or exchange rate change prior to the announcement date. We compute these unconditional standard deviations using data from January 1, 2017 through the day prior to the first QE announcement, which leaves us with nearly 1,000 observations.

Note finally that the Fama et al. (1969) approach generally attempts to measure abnormal stock returns by subtracting predicted returns based on a pre-event window regression from realized returns. The event studies analyzing fixed income markets of Krishnamurthy and Vissing-Jorgensen (2011) and Gagnon et al. (2010), however, do not make this adjustment as pre-event average yield changes are typically negligible.

\section{Event Set}

Table 1 summarizes the list of 30 COVID-19 QE announcements from 21 central banks that we analyze. This is a very large sample of QE uncoordinated and staggered interventions by the standards of the extant literature. ${ }^{1}$ Since we want to estimate the impacts of sovereign bond purchases announcements, we do not consider events involving buying or plans to buy other type of assets without interventions in government or government-backed securities.

For example, we exclude the Bank of Japan's announcement on March 16, 2020 relating to additional purchases of corporate bonds, stocks, and real estate ETF purchases. Similarly, we do not consider the Central Bank of Chile announcement on March 23, 2020 related to the intention to buy bank debt. We also exclude from the sample announcements of legislative initiatives providing

\footnotetext{
${ }^{1}$ A short narrative description of each event is reported in the Appendix together with a link to the corresponding central bank statements
} 
central banks with the legal authority to intervene in the government bond market, as for example, in Brazil. We thus isolate $10 \mathrm{QE}$ announcements made by 8 developed market central banks and 20 announcements made by 13 emerging market central banks. Eight central banks intervened multiple times. In particular, the Fed initially announced a $\$ 700$ billion purchase of Treasuries and MBS on March 16, 2020 and then announced a commitment to "unlimited" purchases on March 23, 2020 together with facilities to support the corporate sector. The Bank of Japan intervened in the government debt market on March 16, 2020 and then again on April 27, 2020. Emerging markets central banks that intervened repeatedly are the Bank of Israel, The National Bank of Poland, The Hungarian National Bank, The Philippines' Central Bank, the Central Bank of Turkey, and the Reserve Bank of India. In these cases, we treat the multiple announcements as separate events as long as they are more than three trading days apart. As subsequent announcements might be partially anticipated to varying degrees, we then check for robustness of the results by excluding all follow up interventions. Several purchase announcements coincide with either simultaneous interest rate cuts or purchases of other assets, such as corporate bonds, equities, commercial paper, or bank assets. Eight central banks announced asset purchases while at the same time lowering policy rates, four of which are advanced economies. Seven central banks intervened simultaneously in the corporate debt market or other markets, five of which are advanced economies. Our large set of announcements allows us to control for these concomitant actions by excluding all instances of government debt purchases accompanied by QE interventions in other markets or policy rate cuts. Table 1 also reports the Fed announcements of the reactivation of the Great Recession era swap lines with major central banks, and the introduction of the new swap lines with smaller advanced economies and major emerging market central banks. ${ }^{2}$ As no QE announcement except Croatia's preceded the Fed first intervention on March 16, we evaluate the role of the Fed swap lines by taking into account the specific date of all QE interventions in the interpretation of the results. Acknowledging that this is not sufficient to reach firmer conclusions, as we noted earlier,

\footnotetext{
${ }^{2}$ On March 31, 2020, the Fed announced a "Temporary Foreign and International Monetary Authorities (FIMA) Repo Facility" accessible also to foreign institutions. We do not discuss this intervention as it came well after the peak of financial turmoil in global asset markets.
} 
Table 1 COVID-19 Quantitative Easing Announcements

\begin{tabular}{|c|c|c|c|c|c|c|}
\hline Country & Central Bank & No. of Events & Date & Size of Government Debt Purchase & Other Asset Purchases & Rate Cut \\
\hline \multicolumn{7}{|c|}{ Developed Markets } \\
\hline U.S. & Federal Reserve & 1 & $3 / 16 / 2020$ & 700 billion USD & Sovereign, MBS & Yes \\
\hline U.S. & Federal Reserve & 2 & $3 / 23 / 2020$ & Unlimited & Sovereign, MBS, Corporate Bonds & No \\
\hline U.K. & Bank of England & 1 & $3 / 19 / 2020$ & 200 billion GBP & Sovereign, Corporate Bonds & No \\
\hline Europe & European Central Bank & 1 & $3 / 19 / 2020$ & 750 billion EUR & Sovereign & Yes \\
\hline Japan & Bank of Japan & 1 & $3 / 16 / 2020$ & JGBs, Corporates & Sovereign, Equities, Corporate Bonds & No \\
\hline Japan & Bank of Japan & 2 & $4 / 27 / 2020$ & Unlimited JGBs & Sovereign, Corporate Bonds & No \\
\hline Canada & Bank of Canada & 1 & $3 / 27 / 2020$ & 5 billion CAD per week & Sovereign, Commercial Paper & Yes \\
\hline Australia & Reserve Bank of Australia & 1 & $3 / 19 / 2020$ & Unlimited & Sovereign & Yes \\
\hline New Zealand & Reserve Bank of New Zealand & 1 & $3 / 23 / 2020$ & 30 billion NZD & Sovereign & No \\
\hline Sweden & Riksbank & 1 & $3 / 16 / 2020$ & 300 billion SEK & Sovereign & No \\
\hline \multicolumn{7}{|c|}{ Emerging Markets } \\
\hline Israel & Bank of Israel & 1 & $3 / 16 / 2020$ & Unspecified amount & Sovereign & No \\
\hline Israel & Bank of Israel & 2 & $3 / 23 / 2020$ & 50 billion ILS & Sovereign & No \\
\hline Korea & Bank of Korea & 1 & $3 / 26 / 2020$ & Unlimited for 3 months & Repos & No \\
\hline Colombia & Banco de la República & 1 & $3 / 24 / 2020$ & 2 trillion COP & Sovereign, Bank Assets & No \\
\hline South Africa & South Africa Reserve Bank & 1 & $3 / 25 / 2020$ & Unspecified amount & Sovereign & No \\
\hline Poland & Narodowy Bank Polski & 1 & $3 / 17 / 2020$ & Unspecified amount & Sovereign & Yes \\
\hline Poland & Narodowy Bank Polski & 2 & $4 / 8 / 2020$ & Unspecified amount & Sovereign, State-Guaranteed Bonds & Yes \\
\hline Romania & Banca Națională a României & 1 & $3 / 20 / 2020$ & Unspecified amount & Repos, Local Government Bonds & Yes \\
\hline Hungary & Magyar Nemzeti Bank & 1 & $4 / 7 / 2020$ & Unspecified amount & Sovereign, MBS & No \\
\hline Hungary & Magyar Nemzeti Bank & 2 & $4 / 28 / 2020$ & 1 trillion HUF & Sovereign, MBS & No \\
\hline Croatia & Hrvatska narodna banka & 1 & $3 / 13 / 2020$ & Unspecified amount & Sovereign & No \\
\hline Phillipines & Bangko Sentral ng Pilipinas & 1 & $3 / 23 / 2020$ & 300 billion PHP & Sovereign & No \\
\hline Phillipines & Bangko Sentral ng Pilipinas & 2 & $4 / 13 / 2020$ & Unspecified amount & Sovereign & No \\
\hline Mexico & Banco de Mexico & 1 & $4 / 21 / 2020$ & 100 billion MXN & Sovereign, Corporate Bonds & Yes \\
\hline Turkey & Central Bank of the of Turkey & 1 & $3 / 31 / 2020$ & Unspecified amount & Sovereign & No \\
\hline Turkey & Central Bank of the of Turkey & 2 & $4 / 17 / 2020$ & $5 \%$ To $10 \%$ of total assets & Sovereign & No \\
\hline India & Reserve Bank of India & 1 & $3 / 18 / 2020$ & 100 billion INR & Sovereign & No \\
\hline India & Reserve Bank of India & 2 & $3 / 20 / 2020$ & 300 billion INR & Sovereign & No \\
\hline India & Reserve Bank of India & 3 & $4 / 23 / 2020$ & 100 bilion INR (twist operation) & Sovereign & No \\
\hline Indonesia & Bank Indonesia & 1 & $4 / 1 / 2020$ & Unspecified amount & Sovereign & No \\
\hline \multicolumn{7}{|c|}{ Fed Swap Lines } \\
\hline \multicolumn{2}{|c|}{ Fed reactivates Great Recession era SWAPS lines } & 1 & $3 / 15 / 2020$ & \multicolumn{3}{|c|}{$\begin{array}{l}\text { Bank of Canada, the Bank of England, the Bank of Japan, } \\
\text { the ECB, and the Swiss National Bank. }\end{array}$} \\
\hline \multicolumn{2}{|c|}{ Fed announces new SWAPS lines with 8 central banks } & 2 & $3 / 19 / 2020$ & \multicolumn{3}{|c|}{$\begin{array}{l}\text { Australia, Brazil, South Korea, Mexico, Singapore, Sweden, } \\
\text { Denmark, Norway and New Zealand (USD } 60 \text { billion each over a period of } 6 \text { months) }\end{array}$} \\
\hline \multicolumn{2}{|c|}{$\begin{array}{l}\text { Announcement of coordinated action to enhance } \\
\text { the provision of global liquidity }\end{array}$} & 3 & $3 / 20 / 2020$ & \multicolumn{3}{|c|}{$\begin{array}{l}\text { Bank of Canada, the Bank of England, the Bank of Japan, } \\
\text { the ECB, and the Swiss National Bank. }\end{array}$} \\
\hline
\end{tabular}

NOTES. The events listed represent all sovereign long-term asset purchase QE events during the COVID-19 pandemic. The table reports the country and the central bank name, whether a central bank intervened repeatedly, the amount announced, and whether a rate cut or a purchase of other assets were simultaneously enacted. The date listed correspond to the day in which we evaluate the market impact and can differ from the announcement day. See the Online Appendix for the announcement details and the links to the corresponding central bank statements. 
we will also analyze the impact of country-specific innovations to nominal 10-year interest rates holding constant changes to a measure of the world interest rate with the GVAR methodology. Table 1 also reports summary information on the size of the announced purchases, illustrating the wide variation across central banks in the size and modalities of intervention. This strengthens our motivation to focus on the QE announcements rather the actual implementation of the purchase programs, under the auxiliary assumption that size and modalities were chosen "optimally" by the central bank given the all information available at the time of intervention.

\section{Financial Market Impact of COVID-19 QE Announcements}

Table 2 reports the estimation results for all events. All impacts are evaluated using daily close quotes. The time series of the bond yields and the level of the bilateral exchange rates are reported in the Appendix Figures B.1 and B.2 since January 1, 2020, together with their respective QE announcement dates. ${ }^{3}$

In the first three columns, we report sovereign bond yield effects, on the same day (one-day window), the day of and the day after (two-day window), and the day of, the day after the announcement, and the subsequent day (three-day window) in percentage point change. As many of the QE interventions refer to "unlimited commitments" or "unspecified amounts", we do not adjust these impacts for size of the announced purchases. In the second three columns, we report exchange rate effects vis-à-vis the US dollar, where an increase is an appreciation, in percentage changes. For the Fed's interventions, we evaluate the exchange rate impact on both the Advanced Economy and Emerging Market Broad Dollar Indexes in units of foreign currency per dollar (an increase is an effective appreciation of the US dollar and a depreciation of the rest of the world).

\footnotetext{
${ }^{3}$ For the United States, the exchange rate series plotted in the Appendix is the Fed Broad Index as in Figure 1.
} 
Table 2 COVID-19 QE Announcement: Bond Yield and Exchange Rate Impacts

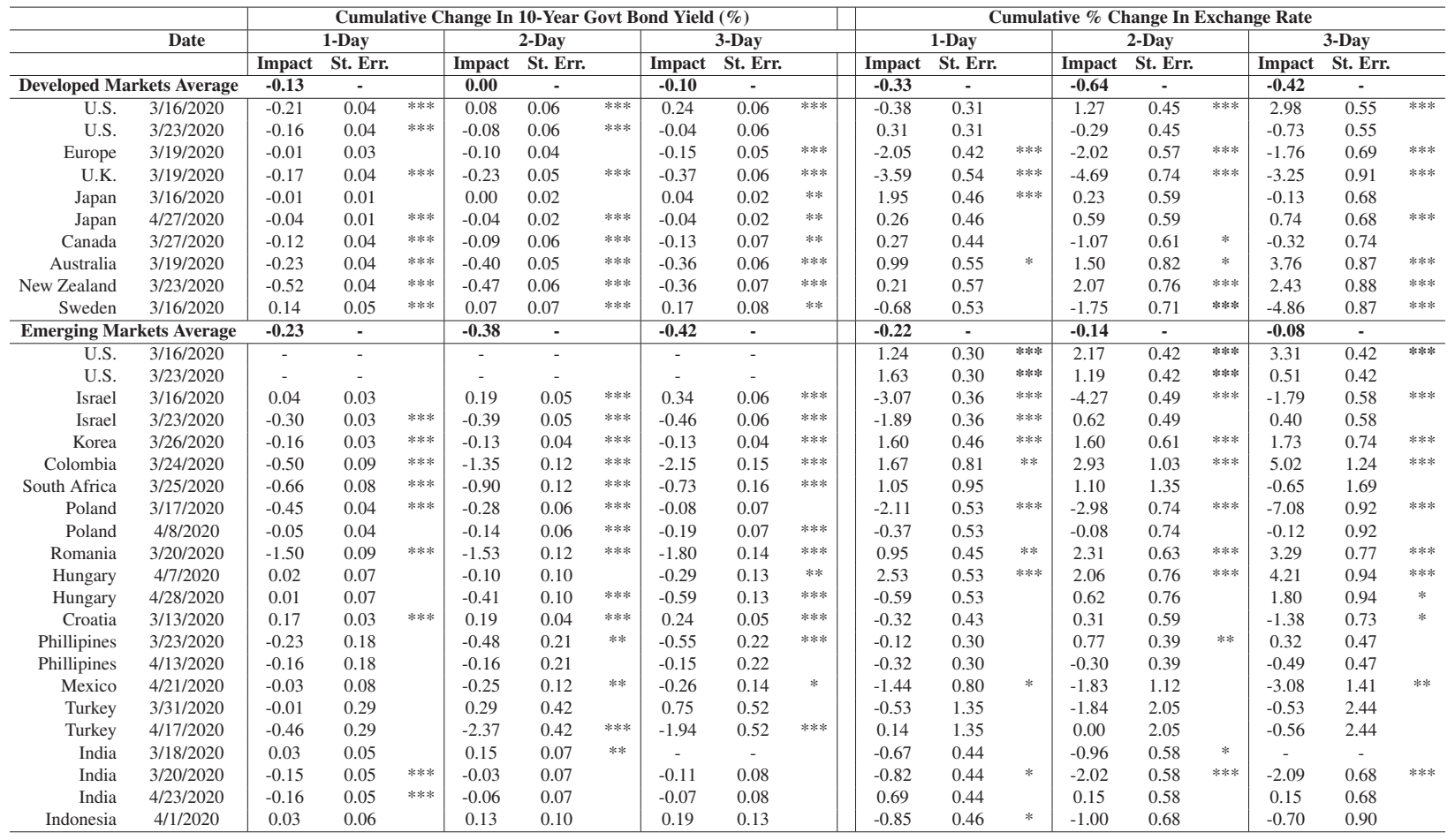

NOTE. The table reports 1-day, 2-day, and 3-day cumulative percentage point change (in \%) in the country's 10-year government bond yield and the percent change (also in \%) in the bilateral exchange rate vs. the US dollar, where an increase is an appreciation. The exchange rate impact of the Fed interventions is assessed on the Fed Broad Index for advanced and emerging markets respectively (Fed release H.10), where an increase is an appreciation. The table also reports the average value across all advanced and emerging economies announcements, where the average for advanced economies excludes the impacts on the US broad dollar index. The impacts are evaluated on the trading day of the announcement, or the first trading day after the announcement if this happened after trading hours or on weekends and holidays. * indicates statistical significance at the $10 \%$ level, ** indicates statistical significance at the $5 \%$ level and $* * *$ indicates statistical significance at the $1 \%$ level. Significance level for the average effects is evaluated using the unconditional standard deviations of the average series reported in the table.

\subsection{Fed Interventions}

The first Fed's QE announcement on March 15, 2020 (a Sunday) had a -0.21\% statistically significant one-day impact on the US 10-year Treasury yield on the subsequent trading day, March 16, 2020. Despite the open-ended nature of the commitment, the second announcement on March 23, 2020 had a smaller, $-0.16 \%$, but statistically significant single-day impact. Treasury yields rose in the two days after both interventions, resulting in a statistically significant three-day yield increase following the first announcement, and a negligible three-day effect after the second intervention. These estimates are very close to the average $-0.15 \%$ impact estimated by Swanson et al. (2011) 
for the six "Operation Twist" events he considers. They are also close to the impacts estimated by Krishnamurthy and Vissing-Jorgensen (2011) for the Fed QE1 large scale asset purchases (LSAP) announcement on November 25, 2008 (-0.36\% two-day impact) and the Fed QE2 announcements on August 10, 2010 and September 21, 2010 (-0.14\% and -0.16\% two-day impacts, respectively). These estimated impacts, therefore, do not suggest that Fed purchases of government assets have lost effectiveness over time, despite the fact that the COVID-19 interventions might have been anticipated to a greater extent than in the past. A more open question is the extent to which they may have had lasting financial market effects or any real economic impact; a question to which we will turn in the last section of the chapter by relying on pre-COVID-19 lower frequency data and the GVAR methodology.

The responses of the US dollar index vis-á-vis advanced economies to these two QE interventions are quite different. On March 16, 2020, the dollar depreciated on impact and then appreciated sharply the following two days, with a cumulative three-day appreciation of almost $3 \%$. ${ }^{4}$ On March 23, 2020, the dollar appreciated on impact, despite the expansion to the other advanced and emerging economy central banks of the swap lines enacted on March 19, 2020, and the enhanced dollar liquidity announcement on March 20, 2020, but then it depreciated during the following two days, with a cumulative three-day depreciation of $0.73 \%$.

Assuming that long-run UIP holds in the data, as for instance documented by Chinn and Meredith (2004) or more recently by (Greenwood, Hanson, Stein and Sunderam, 2020), these exchange rate impacts imply that a major dollar shortage shock realized during the third week of March 2020. For example, the estimated impact of the Fed QE announcements are broadly consistent with the predictions of segmented asset market models of government bond term premia and exchange rate determination (Gourinchas, Walker and Vayanos, 2019, Greenwood, Hanson, Stein and Sunderam, 2020), and the special role of the US dollar in the international financial system. In these models, asset quantities matter, and QE policy is not neutral. Fed government debt purchases reduce the term premium on treasuries demanded by habitat-investors, and hence long-term interest rates. In

\footnotetext{
${ }^{4}$ This happened notwithstanding the reactivation of the Great Recession era swap lines with major central banks announced on Sunday, March 15, 2020.
} 
this setting, Fed QE should also depreciate the US dollar as long as there is no exchange rate risk premium for foreign investors (i.e., long-run UIP holds). The dollar, however, tends to appreciate during periods of global financial turmoil such as during the global financial crisis (Ahmed, 2020). Hence, the dollar can appreciate even after QE interventions, depending on which effect dominates. Overall, our findings suggest that, during the most acute phase of the COVID-19 financial crisis, on March 17, 18 and 19, with a roughly unchanged long-term interest rate differential vis-á-vis other advanced economies as a result of QE interventions on both side of the US parities, a large dollar shortage (or demand) shock drove the dollar appreciation. The Fed did repeatedly respond to this shock with the swap lines, increasing the dollar supply, but with only mixed results, thus leaving room for country-specific interventions to fill the gap.

\subsection{Other Advanced Central Bank Interventions}

The ECB announced a purchase program for an additional 750 billion EUR of sovereign bonds on March 19, 2020. While the initial response of the German Bund yield was muted, over the threeday window, it fell by a cumulative $-0.15 \%$, which is about the same as the estimated one-day impact of the second Fed intervention on March 23, 2020. ${ }^{5}$ The ECB intervention, four days after the reactivation of the Fed swap lines and on the same day of the announcement of the new Fed lines, is associated with a sharp depreciation of the Euro vis-á-vis the US dollar of about $2 \%$ within the one-day window. In this case, the QE supply shock and the dollar exchange rate premium shock pushed the dollar/euro rate in the same direction. This is a second piece of evidence suggesting that, while the swap lines may have been effective in containing covered interest rate parity (CIP) deviations (Bahaj and Reis, 2020), they were less effective in stabilizing the spot exchange rate of the dollar.

Looking at other developed countries, one-day impacts on bond yields varied in a range between a statistically significant $-0.52 \%$ for Australia to the muted effect of $-0.01 \%$ for Japan. Interestingly, Canada and the United Kingdom show one-day impacts comparable to those of the

\footnotetext{
${ }^{5}$ Note here that the Bund yield fell while being in markedly negative territory (Appendix Figure B.2)
} 
second Fed intervention, while in Australia and New Zealand, which announced government asset purchases for the first time under COVID-19, the effects are much larger and comparable to the first Fed interventions on March 16, 2020. In these two countries, the three-day cumulative impact is about as large as in emerging markets, slightly less than $-0.40 \%$, which is indicative of persistent effects. This is clear evidence that unexpected QE interventions have stronger effects than more predictable ones. As in the case of the ECB, these other developed markets QE announcements are accompanied by large exchange rate depreciations that can be rationalized with a combination of two plausible shocks, both pushing bilateral parities in the same direction, only partially offset by the swap lines announcements. The only developed country in which QE intervention appears to have failed is Sweden, which saw bond yields rising and the exchange rate depreciating by almost 5\%. Note, however, that Sweden is the only central bank that announced a QE purchase on the first trading day after the first Fed action on March 15, 2020. This arguably indicates that country-specific QE might have more limited effectiveness in response to global financial shock but could also reflects other forces at work. This also suggests that the remarkable turnaround in world government bond markets started on March 18, 2020 and evident in 1 must be somehow causally related to the Fed interventions, despite the fact that its individual interventions appear to have had only temporary effects.

\subsection{Emerging Market Interventions}

In emerging markets, the responses of local-currency government bond yields to QE announcements are, on average, 2-4 times stronger than in advanced economies and increasing over time (Table 2), and thus more persistent. This is in line with the more unpredictable nature of their interventions, similar to what we saw in the case of Australia and New Zealand. These effects also likely reflect the slower information incorporation and lower liquidity in these markets. In fact, emerging market central banks announced QE interventions for the first time ever in response to COVID-19, even before the monetary policy rates reached the zero-lower bound in most of the cases. 
Figure 2 Average Developed and Emerging Market QE Impacts

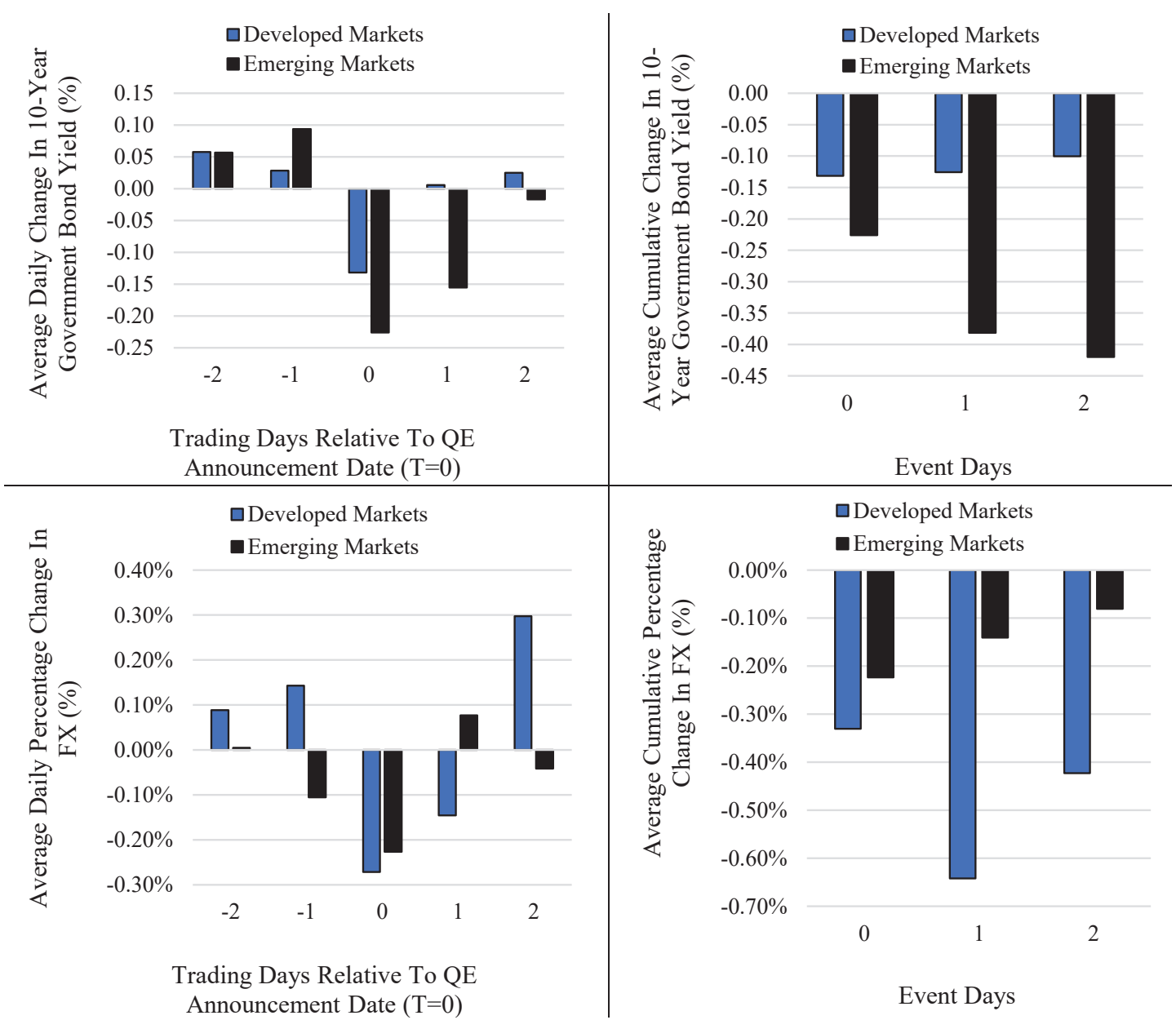

NOTE. The figure compares the QE impacts in emerging markets and advanced economies. The two panels on the left-hand side plot average daily percentage changes in a country's 10-year government bond yield and exchange rate In this case, the QE supply shock and the dollar exchange rate premium shock pushed the Dollar/Euro rate in the same direction relative to its respective QE announcement date. The two panels on the right-hand side plot the average cumulative effects relative to the respective $\mathrm{QE}$ announcement date. The top and bottom panels report bond yields and exchange rate impacts, respectively, as in Table 2. Developed markets, light blue bars. Emerging markets: dark blue bars.

Romania's announcement on March 20, 2020, before global foreign exchange rate markets stabilized, is an example of a successful intervention, with bond yields falling almost $2 \%$ and the exchange rate appreciating more than $3 \%$ in a statistically significant manner within the three-day window: Indonesia's announcement on April 1, 2020, which came well after the global dollar short-age ended, is an example of a failed intervention, with no statistically significant impacts, experiencing yields inching up and the exchange rate under downward pressure. Poland's first QE intervention on March 17, 2020, before the extension of the swap lines on March 19, 2020, man- 
aged to lower bond yields but, as in the case of the ECB's announcement on March 19, 2020, is associated with a massive depreciation. Many emerging market QE interventions are associated with falling bond yields and exchange rate appreciations or slowing depreciations, albeit with significant heterogeneity (Table 2 and Figure 2). A total of 13 out of 20 interventions are associated with one-day appreciations, and 11 out of 20 events with appreciations within the three-day window. Most strikingly, the average depreciation across all interventions is much smaller than in advanced countries (excluding the impacts on the US broad dollar index). By comparison, during the global financial crisis, emerging market currencies depreciated more than advanced economies and their local-currency bond yields increased even after the adoption of QE by the Fed, the ECB, and other major central banks (IMF, 2009). Assuming that QE lowered the supply of local-currency bonds traded in the market and a large dollar shortage shock is in the data during this period, these results represent a puzzle that begs for an explanation.

Emerging market exchange rates have benefited from the reintroduction and the extension of the Fed swap lines, but this is not the whole story. Table 2 shows that all developed and emerging country QE interventions before (Croatia's March 13, 2020), on (Sweden and Israel's first intervention on March 16, 2020), or immediately after (Poland and India's first interventions on March 17, 2020 and March 18, 2020, respectively) the reintroduction of the Fed swap lines on March 15, 2020 failed. However, only Mexico and Korea gained direct access to the extension of the swap lines on March 19, 2020, with one country depreciating and the other appreciating in response to their own QE interventions on March 21, 2020 and March 26, 2020, respectively. Moreover, when we compare the response of the US broad dollar index vis-á-vis advanced economies with the response of the index vis-á-vis emerging markets, which includes both currencies treated with QE and non-treated currencies, we see that the emerging market broad dollar index depreciated much more than advanced economies, consistent with the historical patterns of exchange rate behavior in these countries (Table 2). This stands in sharp contrast with the comparison between the average impact of QE interventions on bilateral exchange rates in the two groups of countries that adopted QE, according to which advanced economies depreciated more than emerging markets (Figure 2). 
This evidence suggests that the transmission of COVID-19 QE interventions on exchange rates in emerging markets is qualitatively different than in developed markets. It also indicates ample scope for country-specific policy interventions over and above the global policy reach of the Fed. One hypothesis here is that there was an additional supportive shock specific to emerging market currencies in the data, such as for instance the simultaneous adoption of foreign exchange intervention. Exchange intervention, however, did not prevent emerging currencies from plummeting during the global financial crisis. Another observation is that COVID-19 itself did not spread to these countries aggressively until well after global financial markets stabilized (Chudik et al., 2020). Yet again, the capital outflow shock was massive (Benigno et al., 2020).

An alternative, more plausible and more easily testable hypothesis is that the transmission channel of QE differs in developed and emerging markets. This is particularly relevant for economies in which foreign investors hold a significant share of the local-currency sovereign debt outstanding. In emerging markets, foreign investors' liabilities tend to be in US dollars, giving rise to currency mismatches in their balance sheets (Bruno and Shin, 2020). As a consequence, a flight to dollar safety can trigger fire sales of local-currency bonds that put pressure on local government bond yields and exchange rates. By being government bond purchasers of "last resort," central banks can counter these forces. Stepping into the market in this manner makes it less likely that foreign investors sell bonds, reducing downward pressure on both bond yields and exchange rates. An alternative channel of transmission is that liquidity provision in the benchmark local bond market can contain the domestic cost of borrowing for the rest of the economy, thereby relaxing corporate borrowing constraints and supporting solvency, ultimately stabilizing both the corporate debt market and the exchange rate. Indeed, the central bank press releases accompanying the QE announcements detail that most interventions were primarily motivated by financial stability considerations and objectives rather the zero-lower bound in a manner consistent with these two hypotheses. 
Table 3 Average Impact Robustness to Alternative Event Sets

\begin{tabular}{|c|c|c|c|c|c|c|}
\hline & \multicolumn{3}{|c|}{$\begin{array}{c}\text { Cumulative Change In 10-Year } \\
\text { Govt Bond Yield }\end{array}$} & \multicolumn{3}{|c|}{$\begin{array}{c}\text { Cumulative \% Change } \\
\text { In FX }\end{array}$} \\
\hline & 1-Day (\%) & 2-Day (\%) & 3-Day (\%) & 1-Day $(\%)$ & 2-Day $(\%)$ & 3-Day (\%) \\
\hline \multicolumn{7}{|c|}{ Advanced Economies } \\
\hline All purchases & -0.13 & -0.13 & -0.10 & -0.33 & -0.64 & -0.42 \\
\hline No Simultaneous Rate Cuts & -0.10 & -0.10 & -0.06 & -0.06 & -0.18 & -0.71 \\
\hline No Corporate Purchases & -0.17 & -0.16 & -0.09 & -0.38 & -0.05 & -0.11 \\
\hline No Simultaneous Rate Cuts or Corporate Purchases & -0.13 & -0.17 & -0.12 & -0.84 & -0.57 & -1.39 \\
\hline Initial Purchases Only & -0.14 & -0.14 & -0.12 & -0.41 & -0.82 & -0.59 \\
\hline \multicolumn{7}{|c|}{ Emerging Markets } \\
\hline All purchases & -0.23 & -0.38 & -0.42 & -0.22 & -0.14 & -0.08 \\
\hline No Simultaneous Rate Cuts & -0.16 & -0.34 & -0.38 & -0.09 & -0.01 & 0.36 \\
\hline No Corporate Purchases & -0.24 & -0.39 & -0.43 & -0.16 & -0.05 & 0.09 \\
\hline No Simultaneous Rate Cuts or Corporate Purchases & -0.16 & -0.34 & -0.38 & -0.09 & -0.01 & 0.36 \\
\hline Initial Purchases Only & -0.25 & -0.31 & -0.37 & -0.10 & -0.14 & -0.05 \\
\hline
\end{tabular}

NotE. The table reports average impacts from Table 2 as well as those calculated with the following four alternative sets: (i) excluding events with simultaneous rate cuts (labeled "No Simultaneous Rate Cuts"); (ii) excluding announcements including purchases of sovereign and other assets (labeled "No Corporate Purchases"); (iii) excluding all events possibly contaminated by these confounding factors (labeled "No Simultaneous Rate Cuts or Corporate Purchases"); and finally (iv), excluding all subsequent events that might be more predictable than the initial ones (labeled "Initial Purchases Only".

\subsection{Robustness}

Table 1 lists the central banks that enacted QE interventions in sovereign and other asset markets or lowered the policy rate at the same time they announced asset purchase programs. The event study also includes multiple announcements from the same central bank. To check robustness of our main findings, Table 3 reports developed and emerging market average impacts for alternative event sets, thus controlling for these possible confounding factors. We consider four alternative sets: (i) excluding events with simultaneous rate cuts; (ii) excluding announcements including purchases of sovereign and other assets; (iii) excluding all events possibly contaminated by these confounding factors; and finally (iv), excluding all subsequent events that might be more predictable than the initial ones.

The average estimate of the impacts on government bond yields are quite robust, and do not differ substantially from our baseline estimates. Excluding QE announcements with simultaneous rate cuts lowers the estimated impacts slightly, as one would expect. The average impact on bilateral exchange rates is more sensitive, given the higher heterogeneity of the individual estimates, especially in emerging markets. The sign of the average one-day and two-day impacts, however, 
does not change, meaning that the direction of the exchange rate response to the QE intervention is estimated robustly. In particular, restricting the event set to initial announcements, which excludes events enacted after the peak of the COVID-19 dollar shortage, results in larger depreciations in advanced economies and smaller ones in emerging markets. This implies that the swap lines were more critical for advanced economies central banks, which had direct access to them. The exclusion of events in which the central bank simultaneously reduced the policy rate and/or announced corporate or other asset purchases results in lower estimated average exchange rate depreciations or larger appreciations, consistent with the hypothesis that central bank liquidity provision to emerging markets might have helped stabilizing the exchange rate through its supportive impact in the domestic corporate sector.

\section{Country-specific QE Effectiveness or US Unconventional Mon- etary Policy Spillovers? Evidence from a GVAR Analysis}

The previous section provides evidence that the large set of uncoordinated and staggered QE interventions in Table 1 had stabilizing impact on local bond markets, and also exchange rates in emerging markets. Nonetheless, the fact that only one central bank intervened before the Fed does not permit to disentangle the importance of country-specific QE interventions relative to the Fed's actions or the joint cumulative effect of the global uncoordinated central bank action. In addition, our high frequency event study does not allow us to evaluate the longer-term financial market effects of QE or its impact on economic activity. Similarly, another important limitation of our event study is that spillovers from early QE announcements to markets in which the central bank intervened later cannot be controlled for with the 30 events in our analysis (e.g., Elenev et al. (2020)). Finally, to interpret the estimation results we have assumed a large dollar shortage shock and also the ability of emerging markets to affect the country-specific component of their exchange rate premium.

In this section, we rely on pre-COVID-19 quarterly data in the context of a multicountry-model 
that takes into account the special role of the dollar and the United States in the world economy to shed lights on these issues. In particular, we explore features of the international transmission of innovations to nominal 10-year interest rates in a standard specification of the GVAR model originally proposed by Pesaran et al. (2004) and Dees et al. (2007) and further developed by CesaBianchi et al. (2012) and Cesa-Bianchi et al. (2020) among others. ${ }^{6}$

\subsection{The GVAR Model}

Table 4 summarizes the GVAR model specification of that we adopt, which is the same as in Dees et al. (2007). ${ }^{7}$ With the exception of the US model, all country VARs include the same set of variables. The variables included are real GDP $\left(y_{i t}\right)$, the inflation rate $\left(\pi_{i t}=p_{i t}-p_{i, t-1}\right)$, the real exchange rate defined as $\left(e_{i t}-p_{i t}\right)$ with an increase denoting a depreciation, the nominal short interest rate $\left(\rho_{i t}^{S}\right.$, typically a three month rate or a policy rate) and, when available, real equity prices $\left(q_{i t}\right)$ and a long-term interest rate $\left(\rho_{i t}^{L}\right.$, typically a ten-year rate).

All country models also include observed and unobserved common factors. All country VARs except the US include the $\log$ of the nominal oil prices $\left(P_{t}^{O}\right)$ as a weakly exogenous variable-a market that was critically destabilized by its own dynamics in March and April 2020. In addition, these VAR models control for the contemporaneous value of four unobserved common factors, estimated as country-specific trade-weighted averages of the corresponding variable in all other countries in the GVAR: the international business cycle ( $y_{i t}^{*}$, as in Cesa-Bianchi et al. (2020) and Kose et al. (2003)), global monetary conditions and inflation $\left(\rho_{i t}^{S *}\right.$ and $\left.\pi_{i t}^{*}\right)$, the world interest rate $\left(\rho_{i t}^{L *}\right)$, and the global financial cycle $\left(q_{i t}^{*}\right)$ as in Acalin and Rebucci (2020).

The US VAR model is specified differently to capture the special role of the United States and its asset markets in the world economy. First, the oil price is included as an endogenous variable.

\footnotetext{
${ }^{6}$ See these references for a summary exposition of the of the GVAR methodology and Pesaran et al. (2004) for a detailed presentation and discussion of the technical aspects of the econometric analysis in this section. See Colabella (2020) and the references therein for a similar analysis of the long-term interest rate shocks in the Euro Area or the United States.

${ }^{7}$ The only important specification changes are that no cointegration vector in any country VARs is restricted, and the different estimation period.
} 
Table 4 Variables Specification of the Country-specific VARX* Models

\begin{tabular}{llll}
\multicolumn{2}{l}{ Non-US Models } & \multicolumn{2}{l}{ US Model } \\
\hline Domestic & Foreign & Domestic & Foreign \\
\hline$y_{i t}$ & $y_{i t}^{*}$ & $y_{U S}$ & $y_{U S}^{*}$ \\
$p_{i t}$ & $p_{i t}^{*}$ & $p_{U S}$ & $p_{U S}^{*}$ \\
$q_{i t}$ & $q_{i t}^{*}$ & $q_{U S}$ & - \\
$\rho_{i t}^{S}$ & $\rho_{i t}^{S *}$ & $\rho_{U S}^{S}$ & $\rho_{U S}^{S *}$ \\
$\rho_{i t}^{L}$ & $\rho_{i t}^{L *}$ & $\rho_{U S}^{L}$ & - \\
$e_{i t}-p_{i t}$ & - & - & $e_{U S}^{*}-p_{U S}^{*}$ \\
- & $p^{0}$ & $p^{0}$ & - \\
\hline
\end{tabular}

Note. The table summarizes the specification of the country-specific VARs that make up the GVAR model. The specification adopted is the same as in Dees et al. (2007), without any restriction on the co-integration space of the VARs other than the rank restriction.

In addition, the US-specific foreign financial variables, $q_{U S, t}^{*}$ and $\rho_{U S, t}^{L *}$, are not included in the US model. Thus, the US long rates and equity risk premium can affect all other countries via the common factors and country-specific spillovers from the United States, but other countries longterm interest rates can affect the US system only via spillovers. Finally, the US VAR is specified so that the real value of the dollar, by construction, is determined outside the US model, as it was treated in our event study. This implies that the US-specific real exchange rate (defined as $\left.e_{U S, t}^{*}-p_{U S, t}^{*}\right)$ is included in the US model as a weakly exogenous foreign variable, while it is an endogenous variable in all other country models.

The country-specific VAR models described in Table 4 are estimated over the period 1999:4 to 2019:4, thus including several episodes of emerging market and global financial instability and crisis such as the Global Financial Crisis and the great recession of 2008-09, but excluding the COVID-19 period. We start the sample in 1999 following Campbell, Pflueger and Viceira (2020), noting that starting in 2000 it is reasonable to assume that US long rates reflect only expected future short rates and term premia, but no inflation risk, as we assumed to interpret the event study results.

All variables except the long-term interest rate are available for most countries. Long-term interest rates since 1999:Q4, which are our main focus in the analysis, are available for the United 
Table 5 Impact of a Unit Change in the World Interest Rate on Domestic Nominal 10-year Rates

\begin{tabular}{ccccccccccccccc}
\hline AUS & CAN & EA & JAP & KOR & NZ & NOR & SA & SWE & SWI & UK & USA & Avg. & Min. & Max. \\
\hline \multirow{2}{*}{0.99} & 0.76 & 0.85 & 0.35 & 0.95 & 1.22 & 0.94 & 0.40 & 1.09 & 0.73 & 0.84 & N.A & 0.83 & 1.22 & 0.35 \\
\hline
\end{tabular}

NOTE. The table reports the contemporaneous impact of the GVAR world interest rate factor on country-specific nominal long-term interest rates.

States, nine other advanced economies, South Korea and South Africa. Thus, the analysis covers all advanced economies in our event studies and two emerging markets, one with access to the Fed swap lines and one without. Note however that the GVAR model is estimated for 32 countries, covering most countries in the event study. ${ }^{8}$

\subsection{The World Interest Rate Factor and Its Loadings}

The first question that we want to address is whether the estimated impacts in our event study reflect only a common factor, say the Fed QE policy action or a world interest rate factor, or they can be the results of country-specific policy actions. Table 7 in Section 5.4 below presents strong evidence that the 12 nominal long-term interest rate series in the GVAR model share at least one strong common factor. Table 7 also shows that the weighted average of the country long rates does an excellent job at capturing it. The innovations to the the log rates equations, in fact, show no sign of sizable residual co-movement once we condition on this proxy of the world interest rate and the other common factors in the country models specified in Table 4.

Based on this preliminary evidence, Table 5 reports the contemporaneous response (i.e., within a quarter) of country specific long-rates to a unit change in the world interest rate factor in the model. By definition of a common factor, these effects can be interpreted causally. The table shows that all countries load positively with exposures ranging widely between from 0.35 to 1.22. This indicates that some of the impacts in our event study must reflect the global nature of the QE interventions adopted or the global reach of the Fed. These loadings, however, illustrate that not

\footnotetext{
${ }^{8}$ The model is estimated with GVAR toolkit version 2.0.; Code and data available from the authors on request for replication purposes.
} 
Table 6 Spillover effect of a unit innovation to nominal long term interest rate

\begin{tabular}{|c|c|c|c|c|c|c|c|c|c|c|c|c|}
\hline & AUS & CAN & EA & JAP & KOR & NOR & NZ & SA & SWE & SWI & UK & USA \\
\hline AUSTRALIA & 1 & 0.20 & 0.26 & 0.35 & 0.17 & 0.05 & 0.04 & 0.00 & 0.21 & 0.12 & 0.24 & 0.66 \\
\hline CANADA & 0.10 & 1 & 0.05 & 0.12 & 0.03 & 0.05 & 0.03 & -0.03 & 0.05 & 0.04 & 0.10 & 0.69 \\
\hline EURO & 0.08 & 0.09 & 1 & 0.19 & 0.08 & -0.06 & 0.03 & 0.01 & 0.12 & 0.14 & 0.26 & 0.61 \\
\hline JAPAN & 0.01 & 0.09 & 0.12 & 1 & 0.05 & -0.02 & -0.02 & -0.02 & 0.09 & 0.03 & 0.06 & 0.31 \\
\hline KOREA & 0.07 & 0.01 & 0.30 & 0.11 & 1 & -0.07 & 0.05 & -0.08 & 0.23 & -0.04 & 0.09 & 0.71 \\
\hline NORWAY & 0.07 & 0.15 & 0.56 & 0.12 & 0.10 & 1 & 0.13 & -0.01 & 0.12 & 0.11 & 0.31 & 0.83 \\
\hline NEW ZEALAND & 0.53 & 0.31 & 0.30 & 0.37 & 0.17 & 0.03 & 1 & -0.01 & 0.27 & 0.14 & 0.47 & 0.63 \\
\hline SOUTH AFRICA & 0.14 & 0.23 & 0.24 & 0.17 & 0.06 & -0.04 & 0.07 & 1 & 0.16 & 0.06 & 0.21 & 0.33 \\
\hline SWEDEN & 0.11 & 0.14 & 0.69 & 0.24 & 0.10 & -0.07 & 0.24 & 0.01 & 1 & 0.22 & 0.38 & 0.69 \\
\hline SWITZERLAND & 0.08 & 0.04 & 0.44 & 0.13 & 0.04 & -0.02 & 0.06 & -0.03 & 0.17 & 1 & 0.21 & 0.53 \\
\hline $\begin{array}{l}\text { UNITED } \\
\text { KINGDOM }\end{array}$ & 0.13 & 0.18 & 0.39 & 0.15 & 0.06 & 0.04 & 0.16 & 0.01 & 0.17 & 0.13 & 1 & 0.60 \\
\hline USA & 0.07 & -0.02 & -0.03 & 0.10 & 0.01 & -0.01 & -0.01 & -0.05 & 0.02 & 0.01 & 0.02 & 1 \\
\hline
\end{tabular}

. Note

all countries move in lockstep with the rest of the world, and the estimated QE impacts in our event study can certainly also be the result of country-specific policy transmission.

\subsection{Spillover Effects from Country-Specific Long-term Interest Rate Changes}

A separate question is the extent to which there might be sizable spillovers in our event study from the uncoordinated implementation of QE. This is important in our event study given the staggered nature of the QE treatments and the limited size of the event set (Cao and Dowd, 2019, Elenev et al., 2020). To address this question, Table 6 reports the contemporaneous effect of a one-standarddeviation country-specific innovation to the long-term interest rate. All impacts are re-scaled so that the effect on the country own long rate is one for ease of presentation.

These estimates confirm that only the Fed can have significant spillover effects on other countries' bond markets. Innovations to all other country interest rate equations tend to have at most regional impact. For example, the innovation to the Japanese long-term interest rate affects New Zealand and Australia, but not other countries. For emerging markets, in particular, spillovers are negligible. This indicates that, in general, spillovers from the staggered implementation of QE should not be an important confounding factor in our event analysis in which the source of the 
shock is identified more precisely and transparently.

\subsection{The Dollar Factor}

Our estimated impacts of the QE announcements in advanced economies are consistent with longrun UIP subject to the auxiliary assumption that a large dollar shortage shock drove the US dollar on the onset of the COVID-19 crisis, and especially during the third week of March. In emerging markets, in contrast, in order to interpret the event study results, we need to assume either additional country-specific shocks that offset the working of the dollar shortage factor or that a different transmission mechanism of country QE is at work.

Table 7 Average Pairwise Cross-Section Correlations: Variables and Residuals

\begin{tabular}{lccccccccc}
\hline & \multicolumn{3}{c}{ All } & \multicolumn{3}{c}{ Advanced Economies } & \multicolumn{2}{c}{ Emerging Economies } \\
\hline \multirow{3}{*}{ Long rates } & Levels & First Differences & Residuals & Levels & First Differences & Residuals & Levels & First Differences & Residuals \\
Exchange rates & 0.89 & 0.54 & 0.01 & 0.91 & 0.59 & 0.02 & 0.79 & 0.26 & -0.01 \\
Output & 0.98 & 0.36 & 0.18 & 0.74 & 0.41 & 0.24 & 0.64 & 0.32 & 0.14 \\
Equity prices & 0.41 & 0.23 & 0.00 & 0.97 & 0.24 & -0.02 & 0.97 & 0.22 & 0.00 \\
\hline
\end{tabular}

One of the critical assumptions underlying the GVAR model is that the cross dependence of the variable-specific reduced form innovations is negligible. Technically, this requires that the country-specific innovations are cross-sectionally weakly correlated, and no strong (i.e., priced) factor remains in the estimated residuals for all model equations (Cesa-Bianchi et al., 2020). Following Dees et al. (2007), it is possible to check this condition by calculating the average pairwise cross-section correlations of all the variables in the GVAR, both in levels and in first-differences, as well as those of the associated residuals of the model equations. The main rationale is that weighted averages of the foreign variables capture the market factors that may be priced in the asset returns included in the GVAR model. Thus, by conditioning the estimation of each country VAR model on the foreign variables in Table 4, we can take account of the common components in the data and render the model residuals cross-sectionally weakly correlated.

The Table 7 below reports the average pairwise cross-sectional correlations for the country variables and the equation residuals. We report these statistics for the long term interest rate, the 
real exchange rate, output, and the real equity price. Although, these results do not constitute a formal statistical test of the importance of the foreign weighted average variables in the GVAR model, they can provide evidence of omitted common factors from the analysis in modeling global interdependence. The results show that the four factors included in the GVAR model-the international business cycles, the global monetary conditions and inflation, as well as the international financial cycle-are soaking up all co-movement in the data and the residuals, except for the exchange rate. The residuals of the exchange rate returns show clear evidence of sizable residual co-movement across countries. We interpret this additional common factor as a dollar factor that can be priced in the cross section of exchange rate returns as in Lustig et al. (2011). Interestingly, however, when we break down advanced and emerging markets, we find that advanced economies load significantly more than emerging markets on the dollar factor, consistent with the results of our event study. This confirms that emerging markets have more margin to affect their own exchange rate with country-specific policy, consistent with the result of our event analysis.

\subsection{Can QE Interventions Have Real Effects?}

A last but important question raised by our event study is whether the effects of QE that we infer from our high-frequency event study can have lasting effects on interest rates themselves and ultimately on real economic activity. The GVAR methodology is uniquely positioned to start providing an answer in a coherent empirical framework. To obtain stylized facts on this transmission beyond the short-term financial market impact, Figure 3 reports the Generalized Impulse Responses Functions (GIRFs) (Pesaran and Shin, 1998) to country-specific innovations to long-term interest rates for selected countries.

The shock that we investigate is a reduced form innovation to the long-term interest rate equation of the country VARs that we consider. Unlike the impacts of the QE events in Section 4, which can be attributed to bond supply rather than demand with a greater degree of confidence, this shock is not structural. However, precisely identifying the source of the interest rate change, whether it ultimately stems from shifts in the bond demand or supply functions or other sources of shocks 
Figure 3 GIRF to a unit country-specific shock to long term interest rates: selected country responses.

\section{Long Term Rate}

US

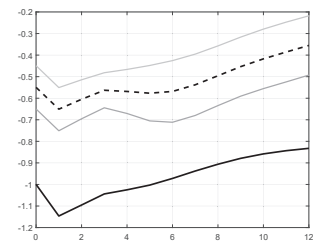

EU

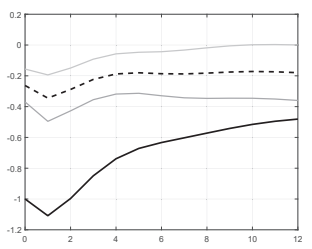

JP

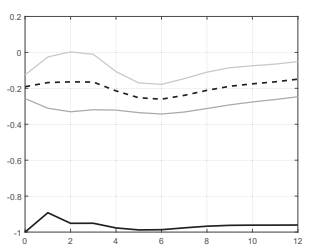

CA

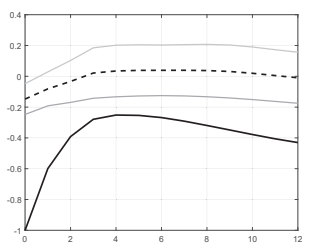

KR

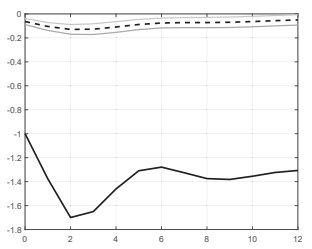

SA

\section{Exchange Rate}
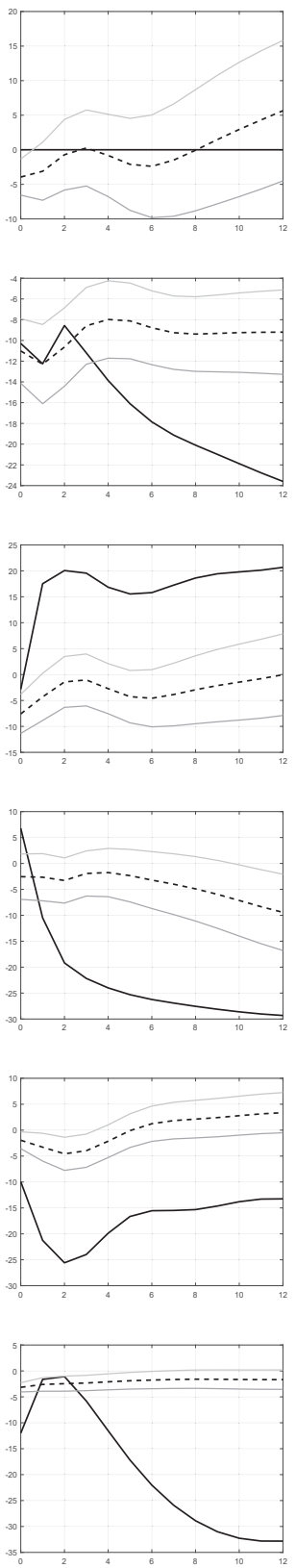

Output
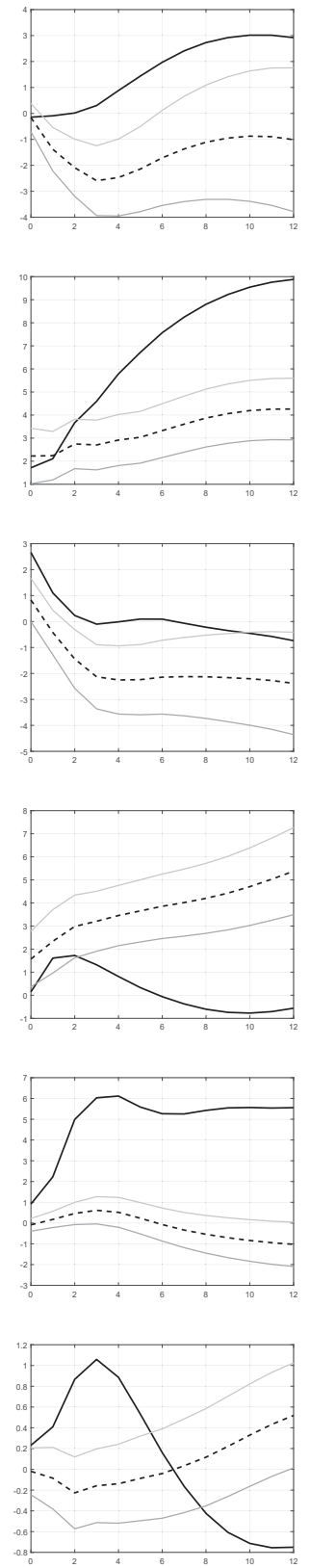

NOTE. The figure plots GIRFs to country-specific unit innovations to long-term interest rates for selected countries (United States, US; the Euro Area, EU; Japan, JP; Canada, CA; South Korea KR, and South Africa, SA). To conserve space, we report the GIRF of the long-term interest rate, the real exchange rate (where an increase is a depreciation for all countries except the US for which is an appreciation), and output as in defined in Table 4. For each country, we plot the own response (solid black line) and the average response of all other countries in the model (dashed black line) that captures spillovers, together with a 90\% confidence band. The confidence bands are computed as the standard deviation of the responses across countries. 
such as a global dollar shortage or a country-specific foreign exchange rate intervention, is less critical to assess the likely persistence of the impulse and the dynamic conditional co-movements of interest rates with output. For this reason, here, we use the GIRF analysis of Pesaran and Shin (1998). GIRFs are invariant to the variable order in the rest of the model and are equivalent to a recursive structural identification in which the long-term interest rate is ordered first in the system. In the GVAR, GIRFs are also conditional on, and hence hold constant, the world interest rate factor as well as all other common factors in the model. Finally, GIRFs take into account any residual contemporaneous correlation across all other innovations in the model. Thus, they take into account multilateral general equilibrium effects.

To conserve space, we plot GIRFs for the United States and a few other selected countries. We report the GIRF of the long-term interest rate, the real exchange rate, and output. For each country, we plot the own response (solid black line), the average response of all other countries in the model (dashed black line) that captures spillovers, and a 90\% confidence band around the average response. $^{9}$

Consider first the United States. A unit innovation to the US long-term interest rate has a persistent effect on the US long rate itself that reverts very slowly to its steady state. As we saw earlier, the spillovers to other countries are sizable, even holding constant the world interest rate, with foreign rates falling by $40-50 \%$ of the US decline. The dollar depreciates on impact vis-a-vis the rest of the world, and significantly more than the drop in interest rates, consistent with the high persistence of the shock. ${ }^{10}$ However it reverts much more quickly than the interest rate, within a year. US output responds only gradually but strongly, peaking within 2 years after the shock. Output spillovers from the shock are much more limited than the financial ones.

In the Euro area, the same shock has a similar impact on long rates and output. The shock, however, appreciates the euro and the effective value of the US dollar vis-à-vis all other currencies rather than depreciating it, perhaps reflecting the reverse channel of causation dominating the co-

\footnotetext{
${ }^{9}$ The confidence bands are computed as the standard deviation of the responses across countries in the spirit of Pesaran and Smith (1995).

${ }^{10}$ For the US shock, the average exchange rate response of other countries represents the US real effective exchange response, as in the event study, where a decline of other countries' exchange rate is a US appreciation.
} 
movement in the data (i.e., the interest rate falling in response to US dollar shortages), or the economic under performance of the Euro Area relative the US during this sample period. Output, however, increases, with a time profile similar to the response of the United States. In Japan, the interest rate response is even more persistent than in the United States or the Euro Area. The exchange rate depreciates as in the United States, but only with a lag, possibly capturing the Bank of Japan propensity to intervene to smooth the Yen's fluctuations. The output response is faster than in Europe and the United States, but less persistent. In Canada, a smaller advanced economy, the exchange rate depreciates on impact and then appreciates, with more muted output effects.

In South Africa and Korea, the only two emerging markets for which we have long-term interest rate series for the whole period, rates fall with essentially no spillovers. In one case, the real exchange rate appreciates, while in the other it depreciates on impact. Nonetheless, output expands in both countries.

We conclude from this last step of the GVAR analysis that shocks to long-term interest rates can have long-lasting impacts on interest rates and output. The response of the exchange rate to interest rate changes is heterogeneous across countries. The results clearly show that the spillovers effects are limited to interest rates changes from major central banks, and particularly the Fed and the ECB. Nonetheless, even emerging markets' country specific actions, which have no spillover effects to other countries, can have strong impact on the level of economic activity in their own countries, even after controlling for global factors. Overall, the results provide encouraging evidence that the turnaround in global bond markets and the subsequent persistent decline in bond yields in response to COVID-19 QE interventions have helped cushion the recessionary effects of the pandemic and could support the global recovery.

\section{Conclusions}

Amid the COVID-19 outbreak and ensuing market panic and economic collapse, global central banks announced new long-term asset purchase programs, the so-called quantitative easing (QE), 
including several emerging markets for the first time. In this paper, we conduct a high-frequency event study analysis of 30 COVID-19 QE announcements of 21 central banks around the world in March and April 2020 on 10-year sovereign bond yields and US dollar exchange rates and investigate the transmission of innovations to long-term interest rates in a standard GVAR model estimated with pre-COVID-19 quarterly data from 1999 to 2019.

We find evidence that QE policy has not lost effectiveness over time, even though less predictable announcements clearly have had larger impacts on bond yields than those that could have been more easily anticipated. In advanced economies, the estimated effects on bond yields and exchange rates are consistent with the working of long-run UIP and the presence of a large dollar shortage shock in the data, to which the Fed responded with enhanced and extended swap lines. The same framework, however, cannot explain the financial market impact of QE in emerging economies. In emerging markets, we need either an additional country-specific shock such as intervention, or a different mechanism to interpret the transmission that we document. These results are robust to controlling for the concomitant reduction of policy rates or asset purchases in other markets, as well as the exclusion of subsequent announcements.

The GVAR evidence that we report illustrates the importance of global factors and the pivotal role of the US Federal Reserve in the transmission of innovations to long rates. Nonetheless, it also illustrates how country-specific interventions can have sizable domestic effects on both longterm government interest rates and output, with more limited spillovers beyond regional impacts. Critically, we show that innovations to long-term interest rates are very persistent, especially in advanced economies. The GVAR results also illustrate the presence of a dollar factor in bilateral real exchange rate returns even after controlling for the world interest rate, the international business cycle, global monetary conditions and inflation, and the global financial cycle. Moreover, we find that emerging economies load less on this common factor than advanced economies, consistent with the results of the event analysis. This is evidence of more asset market segmentation in emerging economies, arguably leaving more scope for country-specific policy interventions.

Overall, our results and analysis show that the Fed played a critical role in stabilizing world 
bond markets and addressing the global dollar shortage triggered by the COVID-19 outbreak. Our findings, however, also provide abundant evidence that individual countries QE interventions contributed significantly and effectively stabilizing local bond and exchange rate markets, after controlling for the Fed's actions, confounding factors, and spillovers from other central bank interventions. 


\section{References}

Acalin, Julien and Alessandro Rebucci, "Global Business and Financial Cycles: A Tale of Two Capital Account Regimes,” Technical Report, National Bureau of Economic Research 2020.

Ahmed, Rashad, "Global Flights-to-Safety and Macroeconomic Adjustment in Emerging Markets," Available at SSRN 3711790, 2020.

Bahaj, Saleem and Ricardo Reis, "Central bank swap lines during the covid-19 pandemic," Covid Economics, 2020, 2.

Barbon, Andrea and Virginia Gianinazzi, "Quantitative easing and equity prices: Evidence from the ETF program of the Bank of Japan," The Review of Asset Pricing Studies, 2019, 9 (2), $210-255$.

Benigno, Gianluca et al., "Sudden Stops and COVID-19: Lessons from Mexico's History," FRBSF Economic Letter, 2020, 2020 (33), 01-05.

Bruno, Valentina and Hyun Song Shin, "Currency depreciation and emerging market corporate distress," Management Science, 2020, 66 (5), 1935-1961.

Campbell, John Y, Carolin Pflueger, and Luis M Viceira, "Macroeconomic drivers of bond and equity risks,” Journal of Political Economy, 2020, 128 (8), 3148-3185.

Cao, Jianfei and Connor Dowd, "Estimation and inference for synthetic control methods with spillover effects," arXiv preprint arXiv:1902.07343, 2019.

Cesa-Bianchi, Ambrogio, M Hashem Pesaran, Alessandro Rebucci, TengTeng Xu, and Roberto Chang, "China's Emergence in the World Economy and Business Cycles in Latin America [with Comment]," Economía, 2012, 12 (2), 1-75.

_, _, and _ , "Uncertainty and economic activity: A multicountry perspective," The Review of Financial Studies, 2020, 33 (8), 3393-3445.

Chinn, Menzie D and Guy Meredith, "Monetary policy and long-horizon uncovered interest parity," IMF staff papers, 2004, 51 (3), 409-430.

Chudik, Alexander, M Hashem Pesaran, and Alessandro Rebucci, "Voluntary and mandatory social distancing: Evidence on covid-19 exposure rates from chinese provinces and selected countries," Technical Report, National Bureau of Economic Research 2020.

Colabella, Andrea, "Do ECB's Monetary Policies Benefit EMEs? A GVAR Analysis on the Global Financial and Sovereign Debt Crises and Postcrises Period," Oxford Bulletin of Economics and Statistics, 2020.

Cortes, Gustavo, George Gao, Felipe Bastos G Silva, and Zhaogang Song, "Unconventional Monetary Policy and Disaster Risk: Evidence from the Subprime and COVID-19 Crises," Available at SSRN 3642970, 2020. 
Dedola, Luca, Georgios Georgiadis, Johannes Gräb, and Arnaud Mehl, "Does a big bazooka matter? Quantitative easing policies and exchange rates," Journal of Monetary Economics, 2020.

Dees, Stephane, Filippo di Mauro, M Hashem Pesaran, and L Vanessa Smith, "Exploring the international linkages of the euro area: a global VAR analysis," Journal of applied econometrics, 2007, 22 (1), 1-38.

Du, Wenxin, Joanne Im, and Jesse Schreger, "The us treasury premium," Journal of International Economics, 2018, 112, 167-181.

D'Amico, Stefania and Thomas B King, "Flow and stock effects of large-scale treasury purchases: Evidence on the importance of local supply," Journal of Financial Economics, 2013, 108 (2), 425-448.

Elenev, Vadim, Luis Quintero, Alessandro Rebucci, and Emilia Simeonova, "Staggered adoption of nonpharmaceutical interventions to contain covid-19 across us counties: Direct and spillover effects," Available at SSRN 3657594, 2020.

Fama, Eugene F, Lawrence Fisher, Michael C Jensen, and Richard Roll, "The adjustment of stock prices to new information," International economic review, 1969, 10 (1), 1-21.

Fleming, Michael J and Eli M Remolona, "Price formation and liquidity in the US Treasury market: The response to public information," The journal of Finance, 1999, 54 (5), 1901-1915.

Gagnon, Joseph, Matthew Raskin, Julie Remache, and Brian P Sack, "Large-scale asset purchases by the Federal Reserve: did they work?," FRB of New York Staff Report, 2010, (441).

Gilchrist, Simon, Bin Wei, Vivian Z Yue, and Egon Zakrajšek, "The fed takes on corporate credit risk: An analysis of the efficacy of the smccf," Technical Report, National Bureau of Economic Research 2020.

Gourinchas, Pierre-Olivier, Rey Walker, and Dimitri Vayanos, "A Preferred-Habitat Model of Term Premia and Currency Risk," mimeo, 2019.

Greenwood, Robin, Samuel G Hanson, Jeremy C Stein, and Adi Sunderam, "A QuantityDriven Theory of Term Premia and Exchange Rates," Technical Report, National Bureau of Economic Research 2020.

Ha, Jongrim and Gene Kindberg-Hanlon, "Asset purchases in emerging markets: Unconventional policies, unconventional times," Technical Report, The World Bank 2020.

Haddad, Valentin, Alan Moreira, and Tyler Muir, "When selling becomes viral: Disruptions in debt markets in the covid-19 crisis and the fed's response," Technical Report, National Bureau of Economic Research 2020.

Hofmann, Boris, Ilhyock Shim, Hyun Song Shin et al., "Emerging market economy exchange rates and local currency bond markets amid the Covid-19 pandemic," Technical Report, Bank for International Settlements 2020. 
IMF, Global Financial Stability Report April 2009: Responding to the Financial Crisis and Measuring Systemic Risks, International Monetary Fund, 2009.

Jones, Charles M, Owen Lamont, and Robin L Lumsdaine, "Macroeconomic news and bond market volatility," Journal of financial economics, 1998, 47 (3), 315-337.

Joyce, Michael AS, Ana Lasaosa, Ibrahim Stevens, and Matthew Tong, "The financial market impact of quantitative easing in the United Kingdom," 26th issue (September 2011) of the International Journal of Central Banking, 2011.

Kose, M Ayhan, Christopher Otrok, and Charles H Whiteman, "International business cycles: World, region, and country-specific factors," american economic review, 2003, 93 (4), 12161239.

Krishnamurthy, Arvind and Annette Vissing-Jorgensen, "The effects of quantitative easing on interest rates: channels and implications for policy," Technical Report, National Bureau of Economic Research 2011.

_, Stefan Nagel, and Annette Vissing-Jorgensen, "ECB policies involving government bond purchases: Impact and channels," Review of Finance, 2018, 22 (1), 1-44.

Lustig, Hanno, Nikolai Roussanov, and Adrien Verdelhan, "Common risk factors in currency markets," The Review of Financial Studies, 2011, 24 (11), 3731-3777.

Pesaran, H Hashem and Yongcheol Shin, "Generalized impulse response analysis in linear multivariate models," Economics letters, 1998, 58 (1), 17-29.

Pesaran, M Hashem and Ron Smith, "Estimating long-run relationships from dynamic heterogeneous panels," Journal of econometrics, 1995, 68 (1), 79-113.

_, Til Schuermann, and Scott M Weiner, "Modeling regional interdependencies using a global error-correcting macroeconometric model," Journal of Business \& Economic Statistics, 2004, $22(2), 129-162$.

Schrimpf, Andreas, Hyun Song Shin, Vladyslav Sushko et al., "Leverage and margin spirals in fixed income markets during the Covid-19 crisis," Technical Report, Bank for International Settlements 2020 .

Sever, Can, Rohit Goel, Dimitris Drakopoulos, Evan Papageorgiou et al., "Effects of Emerging Market Asset Purchase Program Announcements on Financial Markets During the COVID-19 Pandemic,” Technical Report, International Monetary Fund 2020.

Swanson, Eric T, Lucrezia Reichlin, and Jonathan H Wright, "Let's Twist Again: A HighFrequency Event-Study Analysis of Operation Twist and Its Implications for QE2 [with Comments and Discussion]," Brookings Papers on Economic Activity, 2011, pp. 151-207.

Vissing-Jorgensen, Annette, "Bond markets in Spring 2020 and the response of the Federal Reserve," mimeo, 2020. 


\section{A Central Bank Announcements}

\section{U.S Federal Reserve}

On 03/15/2020, the Fed announced 700 billion USD of new Treasury and MBS QE in addition to cutting the federal funds rate range from 1.00\%-1.25\% to 0.00\%-0.25\% (https: / / www. fede ralreserve.gov/newsevents/pressreleases/monetary20200315a1.htm). We select the first subsequent trading date, 03/16/2020, as the event date. On 03/23/2020, the Fed announced potentially "unlimited" MBS and Treasury QE (meeting our criteria for an event date) as well as a host of new facilities including the Primary Market Corporate Credit Facility (PMCCF) and Secondary Market Corporate Credit Facility (SMCCF) (https://www. federalreserve.gov/n ewsevents/pressreleases/monetary20200323b.htm).

On 04/09/2020, the Fed announced it would include high yield bonds in the PMCCF and the SMCCF that had at least one investment grade rating prior to 03/23/2020 and at least two current $\mathrm{BB}$ ratings. We do not include this as an event date since the announcement does not involve the direct purchase of government bonds.

During this period, the Fed also made several announcements related to the establishment of international swap lines. On 03/15/2020 (https: / / www. federalreserve.gov/newsevents / pressreleases/monetary20200315c.htm), the Fed announced it was reactivating its Great Recession era permanent U.S. dollar liquidity swap line arrangements with the Bank of Canada, the Bank of England, the Bank of Japan, the European Central Bank, and the Swiss National Bank. On 03/19/2020, the Fed announced new central bank swap lines with 8 additional central banks (in Australia, Brazil, South Korea, Mexico, Singapore, Sweden, Denmark, Norway and New Zealand), with a commitment to provide $\$ 60$ billion in U.S. dollar liquidity for each central bank over a period of 6 months (https: / /www. federalreserve.gov/newsevents/pressrelease s/monetary20200319b.htm). On 03/20/2020, Bank of Canada, the Bank of England, the Bank of Japan, the European Central Bank, and the Swiss National Bank announced coordinated action to further enhance the provision of global liquidity (https://www. federalreserve.gov/newse vents/pressreleases/monetary20200320a.htm). Note that while the G7 on a conference call on 03/03/2020 agreed to taking coordinated stimulus measures, they postponed any action. We also note that there were no instances of coordinated QE.

\section{Bank of England}

On the evening of 03/18/2020, the Bank of England (BoE) announced it would purchase 200 billion GBP worth of U.K. gilts: https: / / www.bankofengland.co.uk/monetary-policysummary-and-minutes/2020/monetary-policy-summary-for-the-special-monetarypolicy-committee-meeting-on-19-march-2020. We select the first subsequent trading date, $03 / 19 / 2020$, as the event date.

\section{European Central Bank}

On the evening of 03/18/2020, the European Central Bank (ECB) announced it would purchase 750 billion EUR worth of various European sovereign bonds (https://www.ecb. europa.eu/pr ess/pr/date/2020/html/ecb.pr200318_1 3949d6f266.en.html). Since the first trading day after the announcement was 03/19/2020, we use 03/19/2020 as the first event date. 


\section{Bank of Japan}

On 03/16/2020, the Bank of Japan pledged to buy risky assets such as exchange-traded funds at an annual pace of around $¥ 12$ trillion JPY (approximately $\$ 112.55$ billion USD), double its previous pace (https://www.boj.or.jp/en/mopo/mpmdeci/state_2020/k200316b.htm/). It also created a new loan program to extend one-year, zero-rate loans to financial institutions to provide lending to firms hit by the virus outbreak. We do not include this event as it only pertains to risky assets and not sovereign bonds. On 04/27/2020, the Bank of Japan also committed to buy unlimited amounts of government bonds (JGBs) by discarding previous guidance to buy them at an annual pace of 80 trillion yen and said it would boost three-fold the maximum amount of corporate bonds and commercial paper it buys to 20 trillion yen (approximately $\$ 186$ billion USD) (https://www.boj.or.jp/en/mopo/mpmdeci/state_2020/k200427a.htm/)Hence, we include both 03/16/2020 and 04/27/2020 as event dates since they both involve the direct purchase of sovereign bonds.

\section{Bank of Canada}

On 03/27/2020, the Bank of Canada (BoC) announced it would purchase \$5 billion CAD per week of Canadian sovereign bonds in addition to commercial paper in a newly created Commercial Paper Purchase Program, marking the first foray into large scale asset purchases by the BoC (http s://www . bankofcanada.ca/2020/03/press-conference-opening-statement-march-272020 /). Meanwhile, the Canada Mortgage Housing Corporate (CMHC) previously announced it would be buying Canadian mortgage bonds. We do not include the latter in our event study since it is not a direct purchase of sovereign bonds. The central bank also cut its benchmark interest rate on $3 / 27 / 2020$ from $0.75 \%$ to $0.25 \%$.

\section{Reserve Bank of Australia}

On 03/19/2020, the Reserve Bank of Australia announced it would purchase an unlimited amount of Australian sovereign bonds (https://www.rba.gov.au/mkt-operations/anno uncements/rba-purchases-of-government-securities.html), hence we include it as an event date. The central bank also cut its benchmark interest rate on 3/19/2020 from $0.50 \%$ to $0.25 \%$.

\section{Reserve Bank of New Zealand}

On 03/23/2020, the Reserve Bank of New Zealand announced it would purchase 30 billion NZD of New Zealand sovereign bonds (https://www.rbnz.govt.nz/markets-and-payment s/domestic-markets/domestic-markets-media-releases/reserve-bank-to-begin-1 arge-scale-asset-purchases-23-march-2020), hence we include it as an event date. The central bank previously cut its benchmark interest rate from $1.00 \%$ to $0.25 \%$ on $03 / 16 / 2020$.

\section{Riksbank}

On 03/16/2020, the Riksbank announced it was buying an additional 300 billion SEK of government bonds in 2020 (https://www.riksbank. se/en-gb/press-and-published/noti ces-and-press-releases/press-releases/2020/minutes-of-the-monetary-policy- 
meeting-held-on-16-march-2020/). Hence, we include it as an event date. In addition, the Riksbank said on the prior Friday, 03/13/2020, it would lend up to 500 billion SEK to Swedish companies via banks. We do not include this as a separate event.

\section{Bank of Israel}

On 03/15/2020, the Bank of Israel announced that it "will carry out open market operations and will purchase in the secondary market government bonds of various types and maturities in the necessary quantities needed to ensure the smooth functioning of the government bond market" (https://www.boi.org.il/en/NewsAndPublications/PressReleases/Pages/15-032020 . aspx). On 03/23/2020, the Bank of Israel committed to buying 50 billion ILS of Israeli government bonds (https://www.boi.org.il/en/NewsAndPublications/PressRelease s/Pages/22-3-20a.aspx). Hence, we include both 03/15/2020 and 03/23/2020 as event dates. Later, on $04 / 10 / 2020$, it reduced its benchmark interest rate from $0.25 \%$ to $0.10 \%$.

\section{Bank of Korea}

On 03/26/2020, the Bank of Korea announced plans to offer "unlimited" repos for three months (https://www.bok.or.kr/viewer/skin/doc.html?fn=202003300556162960.pdf\&rs=/w ebview/result/E0000634/202003). Hence, we include it as an event date. It previously cut its benchmark interest rate from $1.25 \%$ to $0.75 \%$ on $03 / 17 / 2020$.

\section{Banco de la República}

Colombia's central bank announced QE measures during an emergency session on 03/23/2020 (https://www.banrep.gov.co/en/banco-republica-central-bank-colombia-injects -permanent-liquidity-economy-purchasing-public-and), the first time any South American central bank announced QE, where it would buy government bonds. Since 3/23/2020 was St. Joseph's day, a public holiday in Colombia where markets were closed, we choose 3/24/2020 as the first event date. The same measure authorized the central bank to buy up to 2 trillion COP worth of Colombia Treasury bonds (TES) before the end of March as well as 10 trillion COP worth of private bonds. It subsequently cut its benchmark interest rate from $4.25 \%$ to $3.75 \%$ on 03/27/2020 and again to $3.25 \%$ on $04 / 30 / 2020$.

\section{South Africa Reserve Bank}

On 3/25/2020, the South African Reserve Bank (SARB) announced it would begin an unspecified amount of South African government bond asset purchases (https://sarb-uat.resbank .co.za/content/dam/sarb/newsroom/Further 20 amendment s\%20to\%20the 20 money 2

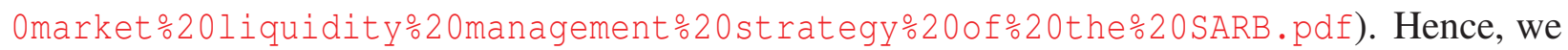
include it as an event date. It previously cut its benchmark interest rate from $6.25 \%$ to $5.25 \%$ on 03/20/2020 and again to $4.25 \%$ on $4 / 15 / 2020$.

\section{National Bank of Romania/Banca Națională a României}

On 03/20/2020, the Romanian central bank had a surprise meeting, announcing it would provide liquidity to banks via repo transactions and purchase local leu-denominated debt on the secondary market to consolidate structural liquidity (https://www.bnr.ro/page.aspx?prid=1761 
7). Hence, we include it as an event date. Romania's central bank also cut its benchmark interest rate by from $2.5 \%$ to $2.0 \%$ on this date.

\section{National Bank of Poland/Narodowy Bank Polski}

On 03/17/2020, the National Bank of Poland received approval to buy an unspecified amount of Polish government bonds from commercial banks. Hence, we include it as an event date. On the same date, it also announced an extension of repo operations increasing banks' liquidity (ht tps: / / www.nbp.pl/en/aktualnosci/2020/mpc_2020_03_17.pdf). The National Bank of Poland announced it was cutting its benchmark interest rate from $1.0 \%$ to $0.5 \%$ on $03 / 17 / 2020$; on 04/08/2020, it announced a ramping up its QE not only buying government bonds but also other bonds with state guarantees, including those issued by the Polish Development Fund (https: //www.nbp.pl/en/aktualnosci/2020/mpc_2020_04_08.pdf). Hence, we include this second event date. The National Bank of Poland announced it was cutting its benchmark interest rate again from $0.5 \%$ to $0 \%$ on $04 / 08 / 2020$.

\section{Croatia National Bank/Hrvatska Narodna Banka}

On 03/13/2020, the Croatian National Bank (CNB) announced it had started to purchase Republic of Croatia government bonds with the aim of maintaining stability in the market of government securities (https://www.hnb.hr/-/savjet-hnb-a-hrvatska-narodna-banka-najav ljuje-strukturnu-operaciju-i-zapocinje-kupovati-obveznice-rh). Hence, we include $3 / 13 / 2020$ as an event date.

\section{Bangko Sentral ng Pilipinas}

On 03/23/2020, the Philippine Monetary Board authorized the Bangko Sentral ng Pilipinas to purchase securities from the Bureau of Treasury (BTr) under a repurchase agreement in the amount of 300 billion PHP with a maximum repayment period of 6 months (https://www.bsp.gov •ph /SitePages/MediaAndResearch/MediaDisp.aspx? ItemId=5221). We include this event, but we date it 03/23/2020 to evaluate its the financial market impact. On 04/09/2020, the Philippine Monetary Board announced it was conducting further asset purchases and expanding the range of eligible securities to cover all peso-denominated Government Securities (GS) issuances (https: //www.bsp.gov.ph/SitePages/MediaAndResearch/MediaDisp.aspx? ItemId=5242). Since 04/09/2020 was Thursday and 04/10/2020 was Good Friday, both bank holidays in the Philippines, we include the following Monday 04/13/2020 as the first event date for this particular intervention. The central bank previously cut its benchmark interest rate from $3.75 \%$ to $3.25 \%$ on 03/19/2020 and again to $2.75 \%$ later on $04 / 17 / 2020$.

\section{Banco de México}

On 04/21/2020, the Banco de Mexico announced 750 billion MXN of economic support, including 100 billion MXN of Mexican government long-term bond asset purchases in addition to a 100 billion MXN corporate securities repurchase facility for securities issued by private nonfinancial institutions (https://www.banxico.org.mx/publications-and-press/other-an nouncements/\%7B6F7FECBA-4 4CB-6AA5-4E4B-269DDBD9B5A8\%7D.pdf). Hence, we include 
$04 / 21 / 2020$ as an event date. On the same day, the central bank also cut its benchmark interest rate from $6.5 \%$ to $6.0 \%$.

\section{Central Bank of the Republic of Turkey}

On 03/31/2020, the Central Bank of Turkey announced it was commencing the purchase of several billion TRY of Turkish government bonds (https://www.tcmb.gov.tr/wps/wcm/co nnect/EN/TCMB+EN/Main+Menu/Announcements/Press+Releases/2020/ANO2020-21). Hence, we include 03/31/2020 as an event date. Previously, on 03/17/2020, the central bank cut its benchmark interest rate from $10.75 \%$ to $9.75 \%$. On 4/17/2020, the central bank announced it was lifting the limit on government bond asset purchases from 5\% to $10 \%$ of Central Bank of Turkey assets (https: / /www.tcmb.gov.tr/wps/wcm/connect/EN/TCMB+EN/Main+Menu/Announcem ents/Press+Releases/2020/ANO2020-22). Hence, we include 4/17/2020 as an event date as well. Later, on $04 / 22 / 2020$, the central bank cut its benchmark interest rate from $9.75 \%$ to $8.75 \%$ and again to $8.25 \%$ on $05 / 21 / 2020$.

\section{Reserve Bank of India}

On 03/18/2020 and 03/20/2020, the Reserve Bank of India announced asset purchases of government bonds. While the announcement on 03/18/2020 only included government bonds up to five years in maturity for a total amount of 100 billion INR(https://www.rbi.org.in/Scrip ts/BS_PressReleaseDisplay.aspx?prid=49534), the second announcement on 03/20/2020 for a total amount of 300 billion INR (https://www.rbi.org.in/Scripts/BS_PressReleas eDisplay aspx?prid=49545) included government bonds up to 9 years in maturity. To avoid potential double counting given the event window overlap (two event dates are only 2 days apart), we include 03/20/2020 and 3/22 as event dates but only include a two day impact for 3/20 to avoid double counting the impact on $3 / 22$. The central bank also later cut its key benchmark interest rate on 03/27/2020. On April 27, 2020 the Reserve Bank of India decided to conduct simultaneous purchase and sale of government securities under Open Market Operations (OMO) for 10,000 crores.

\section{Bank Indonesia}

On 04/01/2020, Bank Indonesia announced the expansion of its authority to purchase long-term government securities $(\mathrm{SBN})$ and government Islamic securities (SBSN) in the primary market (https://www.bi.go.id/en/publikasi/ruang-media/news-release/Pages/sp_22262 0 . aspx). Hence, we include $04 / 01 / 2020$ as an event date. The central bank had previously cut its benchmark interest rate on 03/19/2020. 


\section{B Figures}

Figure B.1 COVID-19 QE Announcements and 10-Year Government Bond Yields: Developed Markets

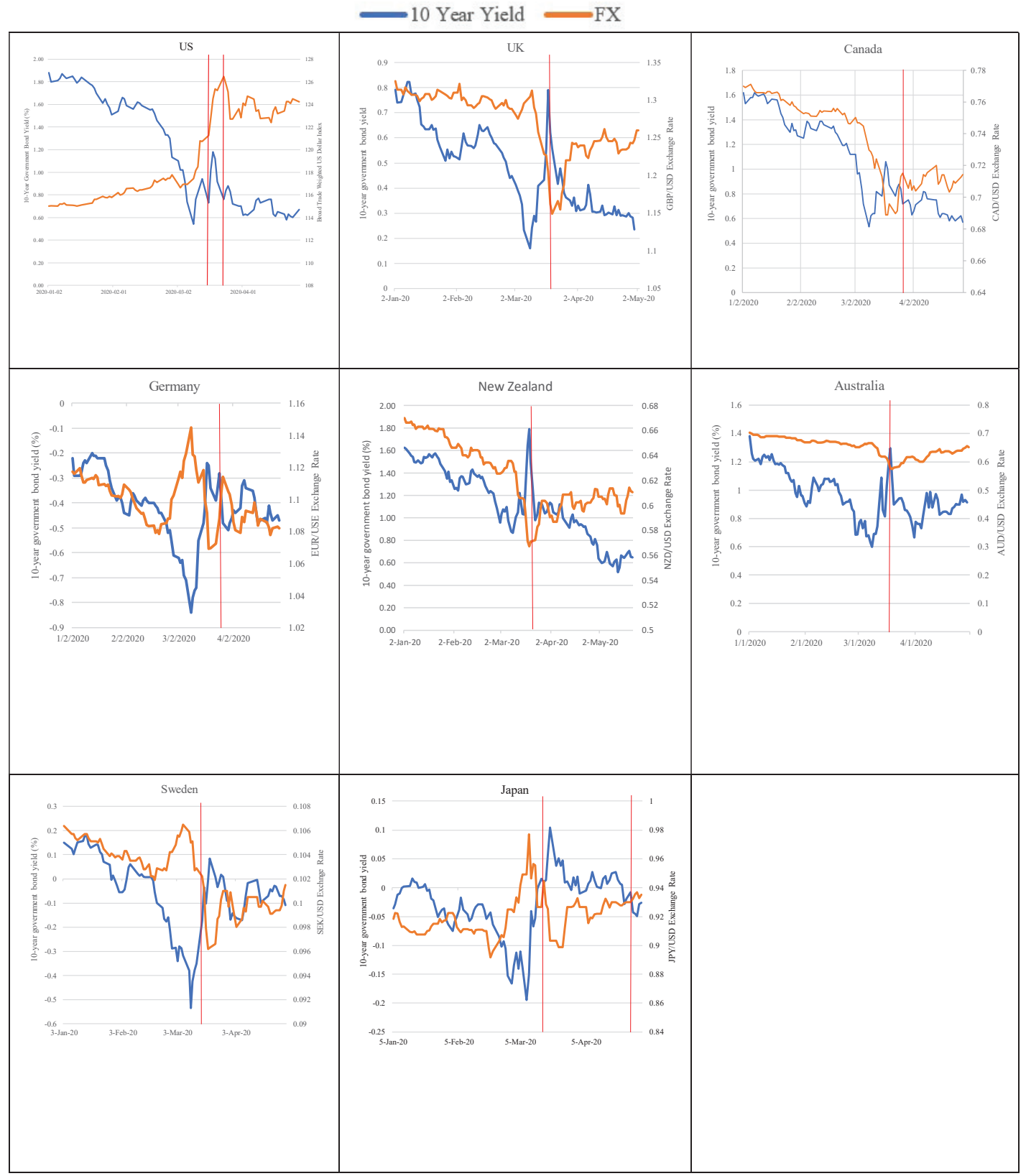

NотE. The figure plots daily market closing 10-year government bond yields for developed markets, from 01/01/2020 to 4/30/2020. Red bars represent central bank QE announcement dates listed in Table 1. Source: Reuters. RIC Tickers in order: US10YT, GB10YT, CA10YT, DE10YT, NZ10YT, AU10YT, JP10YT, SE10YT. 
Figure B.2 COVID-19 QE Announcements and 10-Year Government Bond Yields: Emerging Markets

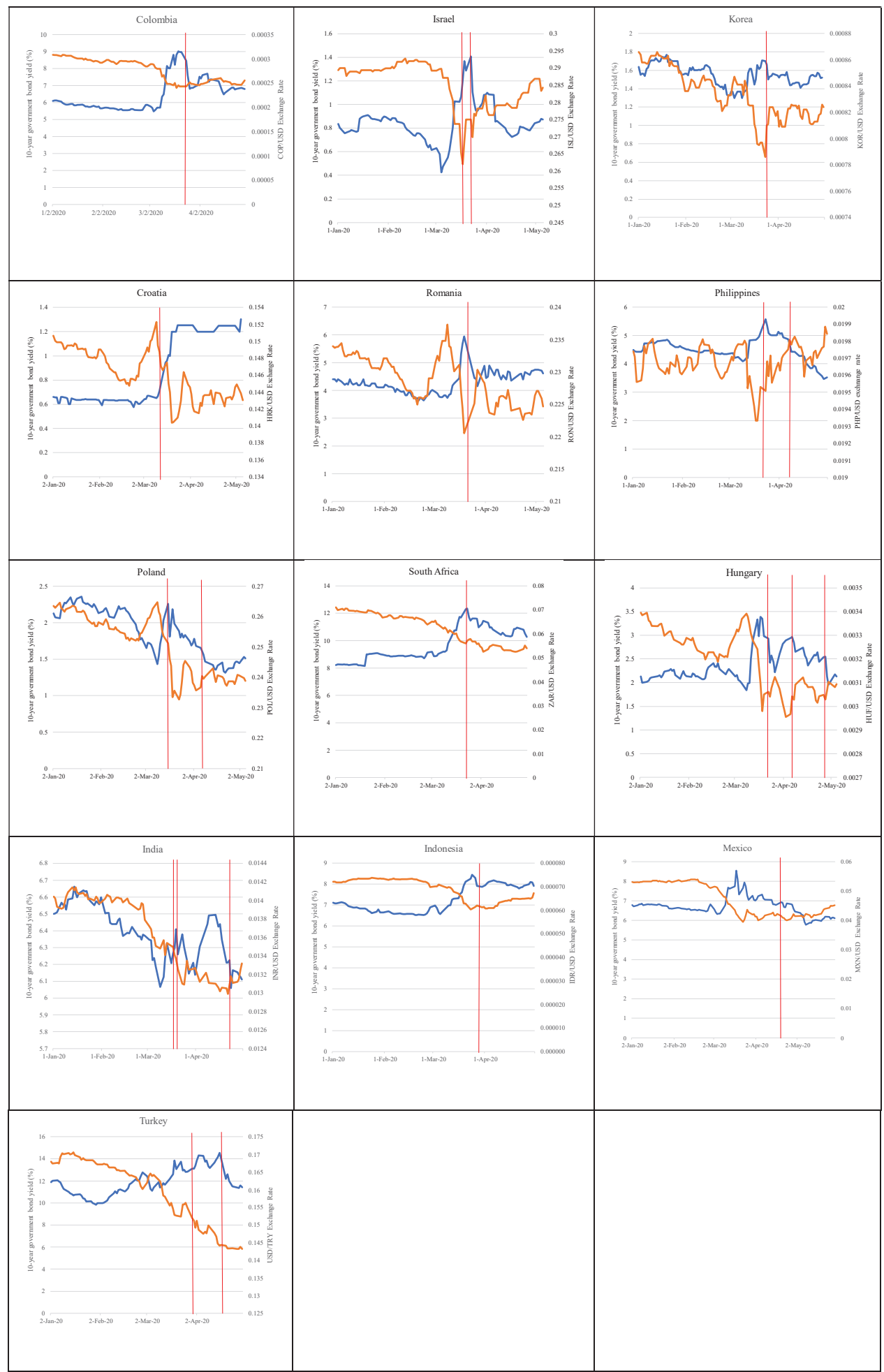

NOTE. The figure plots daily market closing 10-year government bond yields for emerging markets, from 01/01/2020 to 4/30/2020. Red bars represent central bank QE announcement dates listed in Table 1. Source: Reuters. RIC Tickers in order: CO10YT, IL10YT, KR10YT, HR10YT, RO10YT, PH10YT, PL10TY, ZA10YT, HU10YT, IN10YT, ID10YT, MX10YT, TR10YT. 